PSU-IRL-SCI 370

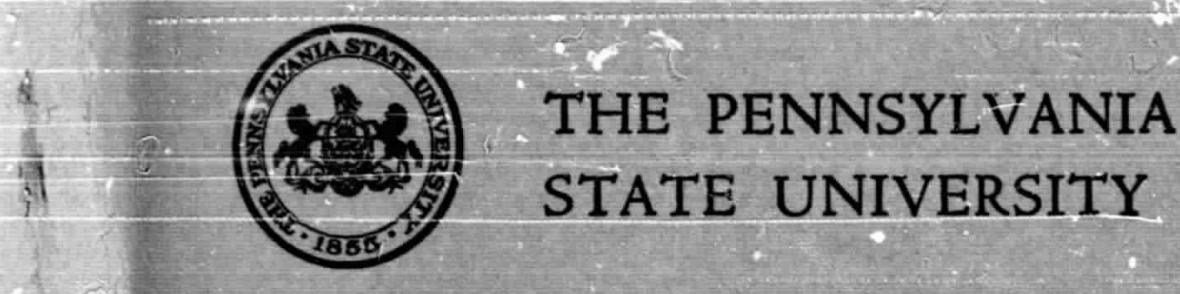

\title{
IONOSPHERIC RESEARCH
}

\author{
Scientific Report No. 370
}

\section{THE MERCURY SENSITIZED OXIDATION * OF CARBON MONOXIDE}

by

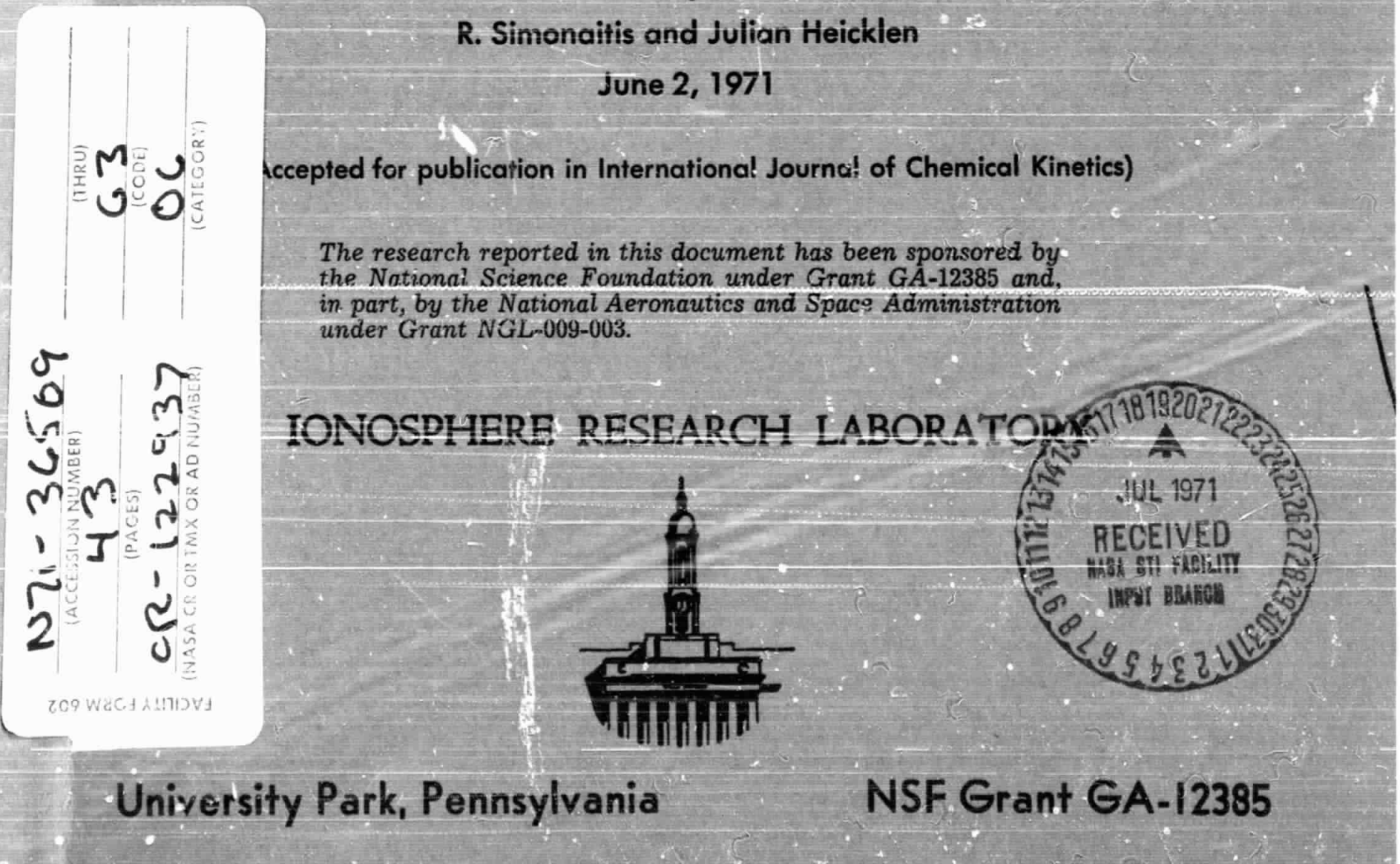




$$
\text { PSU - IRL - SCI } 370
$$

Scientific Report 370

NSF Grant GA-12385

The Mercury Sensitized Oxidation of Carbon Monoxide

by

R. Simonaitis and Julian Heicklen

June 2, 1971

(Accepted for publication in International Journal of Chemical Kinetics)

"The research reported in this document has been sponsored by the National Science Foundation under Grant GA-12385 and, in part, by the National Aeronautics and Space Administration under Grant NGL 009-003.

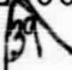

Submitted by:

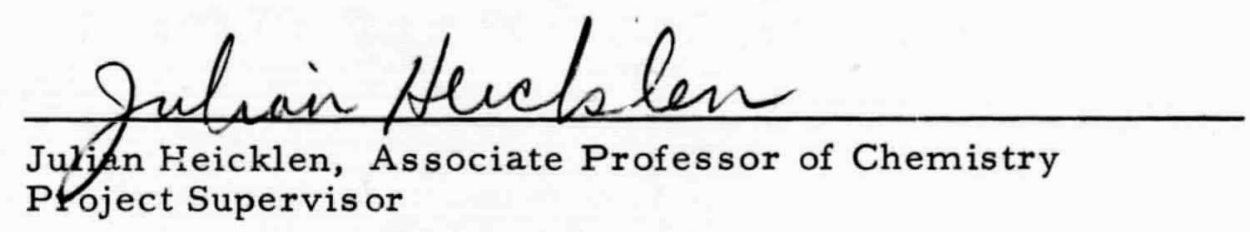

Approved by: Hollidet

J. S. Nisbet, Director

Ionospherc Research Laboratory

Ionosphere Research Laboratory

The Pennsylvania State University

University Park, Pennsylvania 16802 
TABLE OF CONTENTS

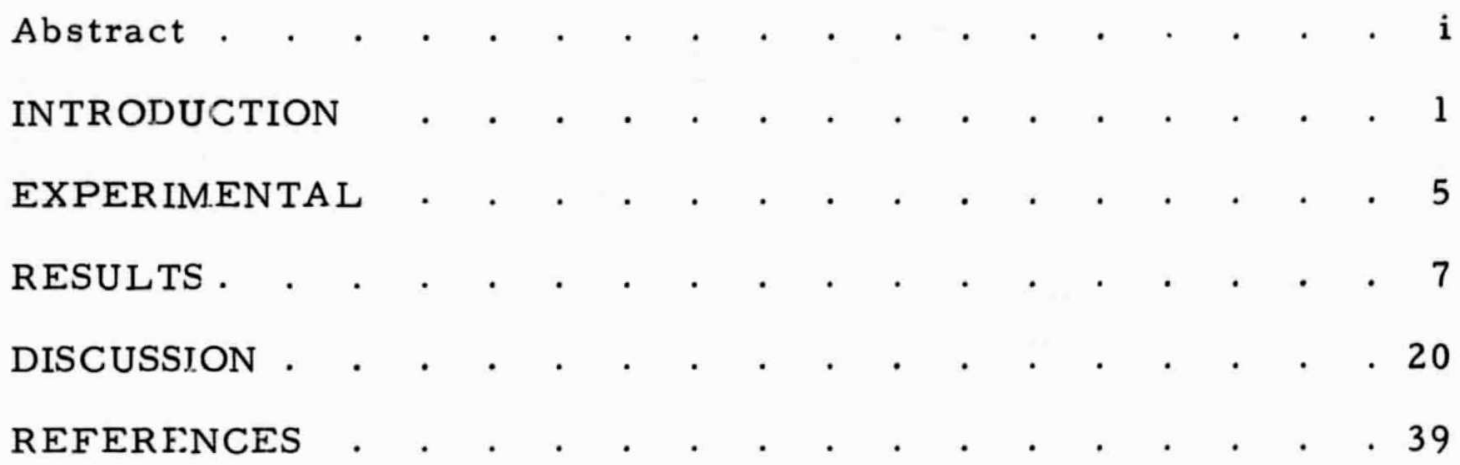




\begin{abstract}
The mercury-photosensitized oxidation of CO was studied at $275^{\circ} \mathrm{C}$ over a wide range of $\left[\mathrm{O}_{2}\right] /[\mathrm{CO}]$ ratios in the absence and presence of the $\mathrm{O}$ atom scavenger 2-trifluoromethylpropene (TMP) and at $25^{\circ} \mathrm{C}$ at low $\left[\mathrm{O}_{2}\right] /[\mathrm{CO}]$ ratios in the presence of TMP. By following the quantum yield of $\mathrm{CO}_{2}$ production, $\Phi\left\{\mathrm{CO}_{2}\right\}$, as a function of the $\left[\mathrm{O}_{2}\right] /[\mathrm{CO}]$ ratio, the reactions of vibrationally excited $C O(v \leq 9)$ and electronically excited $\mathrm{O}_{2}$, probably in the $c^{1} \Sigma_{\mathrm{u}}^{-}$state, were studied. At low $\left[\mathrm{O}_{2}\right] /[\mathrm{CO}]$ ratios the predominant reactions s re of vibrationally excited $C O(v \leq 9)$. Relative rate constants for chemical reaction vs. deactivation of CO $(\mathrm{v} \leq 9)$ were obtained. At higher $\left[\mathrm{O}_{2}\right] /[\mathrm{CO}]$ ratios the principal reactions are of electronically excited $\mathrm{O}_{2}$. Relative rate constants for chemical reactions and deactivation of this electronically excited $\mathrm{O}_{2}$ with $\mathrm{CO}, \mathrm{O}_{2}$ and TMP were obtained. From the effect of total pressure on $\Phi\left\{\mathrm{CO}_{2}\right\}$, it is proposed that an intermediate $\mathrm{CO}_{3}$ is formed in the reaction of electronically excited $\mathrm{O}_{2}$ with $\mathrm{CO}$.
\end{abstract}


INTRODUCTION

Recombination of oxygen atoms will give rise to a number of high lying electronic states of oxygen. Oxygen in the $A^{3} \Sigma_{u}^{+}$state is known to be present in the earth's upper atmosphere as evidenced from the Herzberg emission bands. It is likely that in the atmosphere the $\mathrm{A}^{3} \Sigma_{\mathrm{u}}^{+}$state is produced from the recombination of oxygen atoms. Consequently, it is expected that the $C^{3} \Delta_{u}$ and $c^{1} \Sigma_{u}^{-}$states will also be present, though direct spectroscopic observations cannot be made because emission from these states is forbidden. Electronically excited $\mathrm{O}_{2}$ may also play a role in the conversion of $\mathrm{CO}$ to $\mathrm{CO}_{2}$ in the atmospheres of Mars and Venus. Thus, a study of the reaction of electronically excited $\mathrm{O}_{2}$ with various species present in planetary atmospheres is of interest.

The $\mathrm{Hg}\left({ }^{3} \mathrm{P}\right)$ sensitization of $\mathrm{O}_{2}$ produces electronically excited $\mathrm{O}_{2}{ }^{1,2}$

$$
\mathrm{Hg}\left({ }^{3} \mathrm{P}_{1}\right)+\mathrm{O}_{2} \rightarrow \mathrm{Hg}\left({ }^{1} \mathrm{~S}_{\mathrm{o}}\right)+\mathrm{O}_{2}^{*}
$$

$\mathrm{Hg}\left({ }^{3} \mathrm{P}_{1}\right)$ is known to be deactivated to the ground state. The exact state of $\mathrm{O}_{2}$ is uncertain but it probably is the $\mathrm{c}^{1} \Sigma_{\mathrm{u}}^{-}$state. ${ }^{3}$ The fact that $\mathrm{O}_{2}^{*}$ does not react with $\mathrm{O}_{2}$ to produce $\mathrm{O}_{3}$ very efficiently excludes the $\mathrm{A}^{3} \mathrm{\Sigma}_{\mathrm{u}}^{+}$ state, but the fact that it does react to some extent excludes the lower states of $\mathrm{O}_{2}$, the $\mathrm{a}^{1} \Delta_{\mathrm{g}}$ and $\mathrm{b}^{1} \Sigma_{\mathrm{g}}^{+}$states. All the transitions between ground-state $\hat{O}_{2}$ and the energetically accessible states are optically forbidden. Mercury sensitization permits the optically spin-forbidden transitions. If this is the only optical selection rule which is relaxed, the $c^{1} \Sigma_{u}^{-}$state is the only permitted product state.

If $\mathrm{Hg}\left({ }^{3} \mathrm{P}_{\mathrm{o}}\right)$ is present, reaction 2 will also occur. 


$$
\left.\mathrm{Hg}\left({ }^{3} \mathrm{P}_{0}\right)+\mathrm{O}_{2} \rightarrow \mathrm{Hg}^{1} \mathrm{~S}_{\mathrm{o}}\right)+\mathrm{O}_{2}^{*}
$$

The mercury is necessarily deactivated to the ${ }^{1} \mathrm{~S}_{0}$ state, but the state of $\mathrm{O}_{2}$ produced is not known. However there is no reason to believe that the $\mathrm{O}_{2}^{*}$ produced in reaction 1 is different from that produced in reaction 2 .

$\mathrm{CO}$ is also effective in deactivating $\mathrm{Hg}\left({ }^{3} \mathrm{P}_{1}\right)$ and $\left.\mathrm{Hg}^{3} \mathrm{P}_{0}\right) .^{4,5}$ In this case, however, electronic excitation of the $\mathrm{CO}$ is not possible, since the energy of the lowest excited electronic state of $\mathrm{CO}$ is well above the available energy of $113 \mathrm{kcal} / \mathrm{mole}$. Scheer and Fine 4 suggested that the electronic energy of the mercury is converted almost completely to vibrational energy of the CO by resonant energy transfer producing $C O$ in the $\mathrm{v}=20$ level.

Karl et al. ${ }^{5}$ found that in the irradiation of $\mathrm{Hg}+\mathrm{CO}$ with $2537 \mathrm{~A}$ resonance radiation both the $\mathrm{Hg}\left({ }^{3} \mathrm{P}_{1}\right)$ and $\mathrm{Hg}\left({ }^{3} \mathrm{P}_{0}\right)$ states were present and that.both are deactivated by $\mathrm{CO}$ to give vibratienally excited $\mathrm{CO}$.

$$
\begin{aligned}
& \mathrm{Hg}\left({ }^{3} \mathrm{P}_{1}\right)+\mathrm{CO} \rightarrow \mathrm{Hg}\left({ }^{1} \mathrm{~S}_{0}\right)+\mathrm{CO}^{\dagger} \\
& \left.\mathrm{Hg}\left({ }^{3} \mathrm{P}_{0}\right)+\mathrm{CO} \rightarrow \mathrm{Hg}^{1} \mathrm{~S}_{0}\right)+\mathrm{CO}^{\dagger}
\end{aligned}
$$

By observing the infrared chemiluminescence of $\mathrm{CO}$, they found that the highest vibrational level of $\mathrm{CO}$ populated is $\mathrm{v}=9$ by both $\left.\mathrm{Hg}^{3} \mathrm{P}_{1}\right)$ and $\left.\mathrm{Hg}^{3}{ }^{3} \mathrm{P}_{\mathrm{O}}\right)$. A set of rate constants for the vibrational population of $\mathrm{CO}$ by $\mathrm{Hg}\left({ }^{3} \mathrm{P}_{\mathrm{i}}\right)$ and $\mathrm{Hg}\left({ }^{3} \mathrm{P}_{0}\right)$ relative to the population of the $\mathrm{v}=9$ level was given. The ise rate constants are: $k_{v=10}=0, k_{v=9}=1.00, k_{v=8}=15$, $k_{v=7}=35, k_{v=6}=43, k_{v=5}=48, k_{v=4}=60, k_{v=3}=70, k_{v=2}=80$. The fact that vibrational levels above $v=9$ are not populated indicates that only $47 \%$ of the electronic ensrgy of the $\mathrm{Hg}$ is converted to vibrational energy 
of the $\mathrm{CO}$, the rest must appear as translational energy of the $\mathrm{Hg}$ atom and translational and rotational energy of the CO. Momentum conservation, however, requires that most of the translational energy be taken up by CO. The CO produced in reaction 3 will possess at the most 53 $\mathrm{kcal} / \mathrm{mole}$ vibrational energy and at least $52 \mathrm{kcal} / \mathrm{mole}$ translational + rotational energy. The $\mathrm{CO}$ produced in reaction 4 will have $5.0 \mathrm{kcal} /$ mole less energy since this is the energy difference between the two $\mathrm{Hg}$ states.

Earlier evidence indicated that reaction 3 was the major process for deactivating $\left.\mathrm{Hg}^{3}{ }^{3} \mathrm{P}_{1}\right)$ by $\mathrm{CO} .{ }^{4}$ However more recent work shows that the major $(78 \%)$ process is ${ }^{6}$

$$
\mathrm{Hg}\left({ }^{3} \mathrm{P}_{1}\right)+\mathrm{CO} \rightarrow \mathrm{Hg}\left({ }^{1} \mathrm{P}_{0}\right)+\mathrm{CO}(\mathrm{v}=1)
$$

The corresponding reaction with $\mathrm{O}_{2}$ does not occur. 7

Heicklen and Johnston ${ }^{2}$ studied the relative reactivity of $\mathrm{O}_{2}^{*}$ produced by $\mathrm{Hg}-$ sensitization with a number of gases, including $\mathrm{O}_{2}$ and $\mathrm{CO}$. Their experiments did not distinguish between physical and chemical quenching since products were not analyzed. Volman ${ }^{1}$ has examined the reaction of $\mathrm{O}_{2}^{*}$ with $\mathrm{O}_{2}$. He found ozone as a product with the quantum yield $\Phi\left\{\mathrm{O}_{3}\right\}$ being about 0.03 , though higher yields have been reported.

One set of objectives of the present investigation was to: 1) examine the products of the reaction between $\mathrm{O}_{2}^{*}$ and $\mathrm{CO}$ (presumably $\mathrm{CO}_{2}$, , 2) obtain the relative degree of physical vs, chemical quenching of $\mathrm{O}_{2}^{*}$ by both $\mathrm{O}_{2}$ and $\mathrm{CO}$, and 3) check the relative quenching efficiency of $\mathrm{O}_{2}^{*}$ by $\mathrm{CO}$ and $\mathrm{O}_{2}$ by a different method. The reaction between $\mathrm{O}_{2}^{*}$ and $\mathrm{CO}$ may produce the intermediate $\mathrm{CO}_{3}$, and it was hoped that kinetic evidance for the presence of this species might be obtained for this 
system. The formation of $\mathrm{CO}_{3}$ produced by the reaction of $\mathrm{O}\left({ }^{1} \mathrm{D}\right)+$ $\mathrm{CO}_{2}$ has been established. ${ }^{8}$

The second major objective was to see if the CO produced in reactions 3 and 4 would react with $\mathrm{O}_{2}$. The translational and rotational energy of the CO produced in reactions 3 and 4 probably will be lost in a few collisions in the presence of high [CO] and low $\left[\mathrm{O}_{2}\right]$, thus leaving a highly vibrationally excited $\mathrm{CO}$ molecule. Thus, this system appeared to be an excellent prototype of a possible bimolecular reaction involving a vibrationally hot, but translationally and rotationally cold, molecule.

In order to prevent the consumption of $\mathrm{Hg}$ by $\mathrm{O}_{3}$ via the reactions

$$
\begin{aligned}
& \mathrm{O}_{2}^{*}+\mathrm{O}_{2} \rightarrow \mathrm{O}_{3}+\mathrm{O} \\
& \mathrm{M}+\mathrm{O}+\mathrm{O}_{2} \rightarrow \mathrm{O}_{3}+\mathrm{M} \\
& \mathrm{O}_{3}+\mathrm{Hg} \rightarrow \mathrm{HgO}+\mathrm{O}_{2}
\end{aligned}
$$

experiments were performed at $275^{\circ} \mathrm{C}$ at which temperature $\mathrm{O}_{3}$ is unstable. Another set of experiments was performed in the presence of 2 -trifluoromethylpropene (TMP) which was expected to serve as a diagnostic test for the presence of oxygen atoms. The reaction of oxygen atoms with TMP has been investigated by Moss and Jennings ${ }^{9}$ and by the present authors. ${ }^{10}$ The reaction is a clean addition of oxygen atoms to give the 2-trifluoromethylpropionaldehyde (A) and 2-trifluoromethylpropylene oxide (E) with $\Phi\{\mathrm{A}\}=0.40$ and $\Phi\{\mathrm{E}\}=0.60$ independent of temperature $\left(25^{\circ}-275^{\circ} \mathrm{C}\right)$ and pressure (> 100 torr). It turned out that in the presence of TMP, experiments could also be performed at room temperature as well, providing the $\left[\mathrm{O}_{2}\right]$ to $[\mathrm{TMP}]$ ratio was $\leq 5.0$. 


\section{EXPERIMENTAL}

The experiments utilized conventional static photochemical techniques. The reaction vessel was a cylindrical quartz cell $5 \mathrm{~cm}$. in diameter and $10 \mathrm{~cm}$. long, jacketed in a wire-wound aluminum furnace with quartz windows. The temperature was regulated to $\pm 1^{\circ} \mathrm{C}$ by a Cole-Parmer Proportio Null Regulator Series V300.

Irradiation was from a Hanovia flat-spiral low-pressure mercury resonance lamp. The radiation passed through a 9-54 Corning filter to remove radiation below $2200 \mathrm{~A}$.

The gases were saturated with $\mathrm{Hg}$ vapor at room temperature and mixed directly in the cell. The CO was purified by passage over glass beads at $-196^{\circ} \mathrm{C}$, degassing at $-196^{\circ} \mathrm{C}$, and distillation from a trap immersed in liquid argon $\left(-186^{\circ} \mathrm{C}\right)$ to a trap maintained at $-196^{\circ} \mathrm{C}$. The 2-trifluoromethylpropene was obtained from Peninsular ChemResearch Inc., and it was purified by preparative gas chromatography on a 1/4-in. diameter by 20 -foot long Porapak $Q$ column operating at $25^{\circ} \mathrm{C}$. Gas chromatographic analysis showed no detectable impurities. $\mathrm{CF}_{4}$ was purified by repeated degassing at $-196^{\circ} \mathrm{C}$ and distillation from a trap at $-160^{\circ} \mathrm{C}$. Air Products and Chemicals Co. Research grade $\mathrm{N}_{2}$ was purified by passage over glass beads at $-196^{\circ} \mathrm{C}$.

For the experiments at $275^{\circ} \mathrm{C}$ the cell contents we re removed immediately to minimize the decomposition of the aldehyde product. The $\mathrm{CO}_{2}$, the 2-trifluoromethylpropionaldehyde, and 2-trifiuoromethylpropylene oxide products were analyzed on a 10 -foot long column at $38^{\circ} \mathrm{C}$ packed with $20 \% \mathrm{Kel}-\mathrm{F}$ oil No, 3 on Chromasorb P.

The actinometry utilized was the mercury sensitized decomposition of $\mathrm{N}_{2} \mathrm{O}$ in the presence of TMP in order to scavenge the $\mathrm{O}$ atoms. 
$-6-$

In this system the rate of $\mathrm{N}_{2}$ production, $R\left\{\mathrm{~N}_{2}\right\}$, equals $I_{a}$, since $\Phi\left\{\mathrm{N}_{2}\right\}=$ 1.00. ${ }^{11}$ The quantum yields of the epoxide and aldehyde were not measured directly since calibrations for $A$ and $E$ were not made. They are based on $\Phi\{\mathrm{A}\}=0.40$ and $\Phi\{\mathrm{E}\}=0.60$ determined by Moss and Jennings at room temperature. ${ }^{9}$ Earlier we have shown ${ }^{10}$ that $\Phi\{E\}$ and $\Phi\{A\}$ in the $\mathrm{N}_{2} \mathrm{O}$-TMP system are independent of temperature from $25^{\circ}-200^{\circ} \mathrm{C}$, and in this investigation it was shown that the yields are also the same at $275^{\circ} \mathrm{C}$. 


\section{RESULTS}

When mixtures of $\mathrm{O}_{2}$ and $\mathrm{CO}$ saturated with $\mathrm{Hg}$ vapor are ir radiated with 2537 A resonance radiation at room temperature, the only product observed is $\mathrm{CO}_{2}$. Presumably ozone is also produced, since the rate of $\mathrm{CO}_{2}$ formation drops to zero after only a few minutes irradiation due to the formation of $\mathrm{HgO}$. For this reason experiments at room temperature in the absence of TMP could not be performed.

When mixtures of $\mathrm{O}_{2}$ and $\mathrm{CO}$ are irradiated in the presence of TMP at room temperature the products observed are $\mathrm{CO}_{2}, 2$-trifluoromethylpropyleneoxide (E) and 2-triflurormethylpropionaldehyde (A), and their rates of formation are independent of irradiation time provided $\left[\mathrm{O}_{2}\right] /[\mathrm{TMP}] \leq 5$. The resuits are presented in Table I. The $[\mathrm{CO}] /\left[\mathrm{O}_{2}\right]$ ratio was varied from 5.22 to 377 . The lower limit was imposed by the conditions that $\left[\mathrm{O}_{2}\right] /[\mathrm{TMP}] \subseteq 5$ and $\left(\left[\mathrm{O}_{2}\right]+0.29[\mathrm{CO}]\right) /[\mathrm{TMP}]>10$. The former condition insures that no $\mathrm{O}$ atoms react with $\mathrm{O}_{2}$ to give $\mathrm{O}_{3}$ and the latter condition that $<10 \%$ of the excited $\mathrm{Hg}$ is quenched by TMP. The upper limit for the $[\mathrm{CO}] /\left[\mathrm{O}_{2}\right]$ ratio is dictated by the necessity to produce sufficient product for analysis.

Two runs were made in the absence of $\mathrm{CO}$ at room temperature to see if $\mathrm{CO}_{2}$, the aldehyde, and the epoxide are products of the reaction between $\mathrm{O}_{2}^{*}$ and TMP.

In the presence of $\mathrm{CO}$ the product yields, $\Phi\left\{\mathrm{CO}_{2}\right\}, \Phi\{\mathrm{A}\}$, and $\Phi\{\mathrm{E}\}$, rise in a regular manner as the $\left[\mathrm{O}_{2}\right] /[\mathrm{CO}]$ ratio increases from 5.22 to 377 . There is considerable scatter in $\Phi\{\mathrm{E}\} / \Phi\{\mathrm{A}\}$, but the average value, 1.50 , is the same as when $\mathrm{O}$ atoms produced in the $\mathrm{Hg}$ sensitized decomposition of $\mathrm{N}_{2} \mathrm{O}$ react with TMP. $\Phi\left\{\mathrm{CO}_{2}\right\}$ is in some runs somewhat greater than $\Phi\{E\}+\Phi\{A\}$. In the absence of $C O$, the 


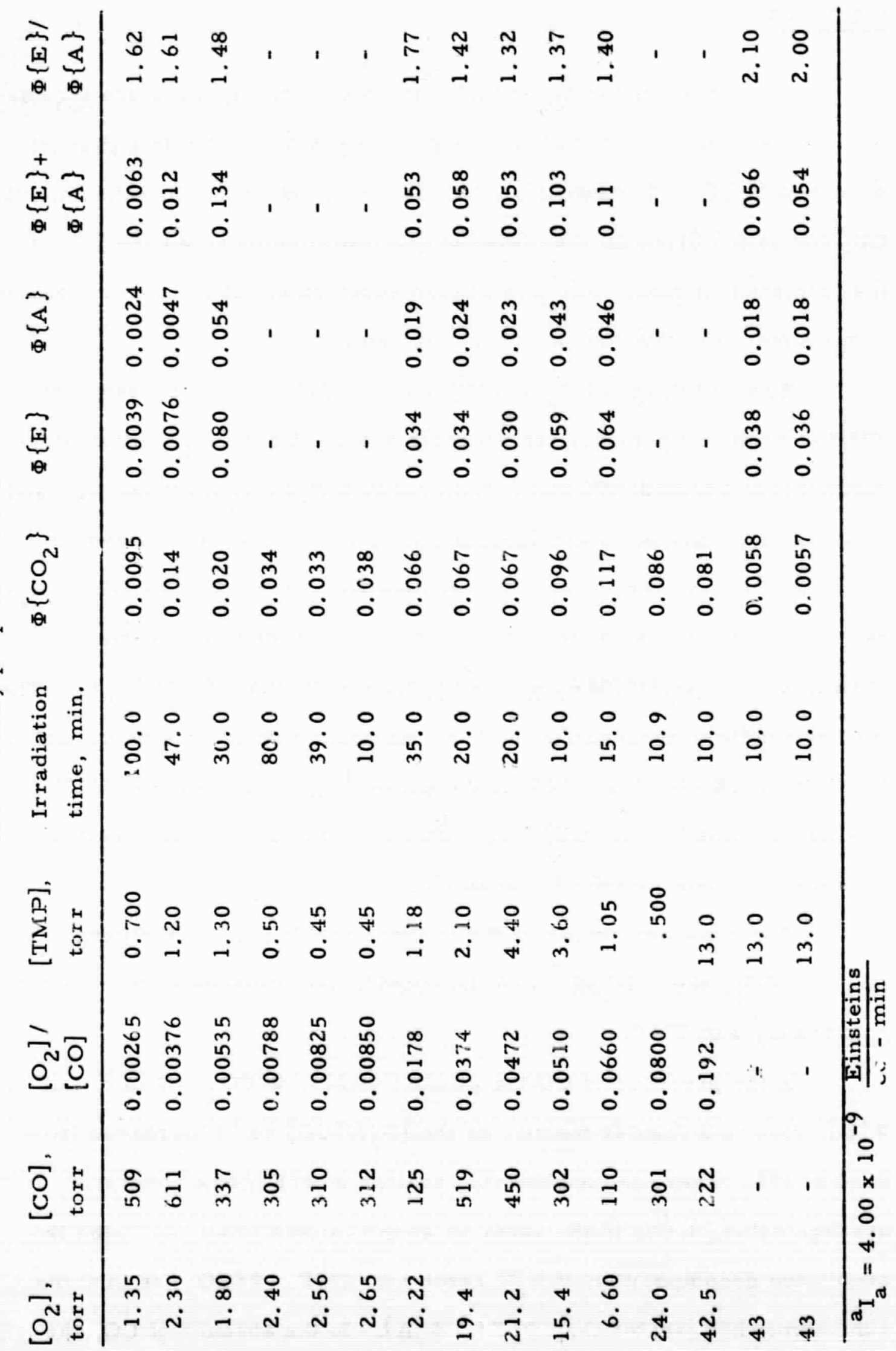


products are still formed, but their yields, particularly of $\mathrm{CO}_{2}$, are very small. The contribution to the yield of these products from the reaction of $\mathrm{O}_{2}^{*}$ with TMP will be negligible for all the runs except for the run with 42.5 torr $\mathrm{O}_{2}$ where the contribution to $\Phi\{\mathrm{E}\}$ and $\Phi\{\mathrm{A}\}$ will be large; hence $\Phi\{\mathrm{E}\}$ and $\Phi\{\mathrm{A}\}$ were not determined for this run.

The results for the $\mathrm{Hg}$-sensitized oxidation of $\mathrm{CO}$ at $275^{\circ} \mathrm{C}$ in the absence of TMP are presented in Table IJ and in the presence of TMP in Table III. Figure 1 displays the data in graphical form. The only prociuct observed at $275^{\circ} \mathrm{C}$ in the absence of TMP is $\mathrm{CO}_{2}$ (in the absence of $\mathrm{O}_{2}$, no $\mathrm{CO}_{2}$ is formed). The rate of $\mathrm{CO}_{2}$ production at $275^{\circ} \mathrm{C}$ was independent of the time of irradiation throughout the whole $\left[\mathrm{O}_{2}\right] /$ [CO] range covered, indicating that at this temperature the equilibrium concentration of $\mathrm{O}_{3}$ is too small for $\mathrm{HgO}$ formation to occur. The $\left[\mathrm{O}_{2}\right] /$ [CO] ratio was changed from 0.00273 to 450 , greater than five orders of magnitude. At any given total pressure (experiments were done at $\sim 50,100$, and 500 tor $\mathrm{r}) \Phi\left\{\mathrm{CO}_{2}\right\}$ rises to a maximum as the ratio of $\left[\mathrm{O}_{2}\right]$ to $[\mathrm{CO}]$ increases and then declines on further increase in $\left[\mathrm{O}_{2}\right] /$ [CO]. For $\left[\mathrm{O}_{2}\right] /[\mathrm{CO}]$ below 0.08 , a change in the total pressure from ح 50 - 500 torr has no effect on $\Phi\left\{\mathrm{CO}_{2}\right\}$, but for $\left[\mathrm{O}_{2}\right] /[\mathrm{CO}]$ above 0.08 , $\Phi\left\{\mathrm{CO}_{2}\right\}$ increases with increasing total pressure. Some runs were done where the major gas was $\mathrm{CF}_{4}$, and some where it was $\mathrm{N}_{2}$ (Table IV). The presence of excess $\mathrm{CF}_{4}$ in the pressure independent regions had no effect upon $\Phi\left\{\mathrm{CO}_{2}\right\}$. In the pressure dependent region increasing the total pressure with $\mathrm{CF}_{4}$ has the same effect as increasing both the $\left[\mathrm{O}_{2}\right]$ and $[\mathrm{CO}]$, while keeping $\left[\mathrm{O}_{2}\right] /[\mathrm{CO}]$ constant. The presence of excess $\mathrm{N}_{2}$ in the pressure-independent region had no effect upon $\Phi\left\{\mathrm{CO}_{2}\right\}$, but in the pressure dependent region $\Phi\left\{\mathrm{CO}_{2}\right\}$ is not enhanced nearly as much 
TABLE II

The $\mathrm{Hg}$-Sensitized Oxidation of $\mathrm{CO}$ at $275^{\circ} \mathrm{C}^{\mathrm{a}}$

$\left[\mathrm{O}_{2}\right]$, torr $[\mathrm{CO}]$, torr $\quad\left[\mathrm{O}_{2}\right] /[\mathrm{CO}] \quad \begin{aligned} & \text { Irradiation } \\ & \text { time, min. }\end{aligned}\left\{\mathrm{CO}_{2}\right\}$

Total Pressure $\sim 500$ torr

$\begin{array}{rcccc}498 & 1.10 & 453 & 10.0 & 0.0897 \\ 535 & 3.60 & 149 & 32.0 & 0.147 \\ 684 & 6.5 & 105 & 30.0 & 0.189 \\ 494 & 5.20 & 95.0 & 20.0 & 0.171 \\ 483 & 14.5 & 33.3 & 10.5 & 0.182 \\ 471 & 26.0 & 18.1 & 10.0 & 0.240 \\ 437 & 70.0 & 6.25 & 10.0 & 0.295 \\ 396 & 101 & 3.93 & 10.0 & 0.322 \\ 430 & 190 & 2.26 & 10.0 & 0.343 \\ 282 & 220 & 1.28 & 10.0 & 0.397 \\ 218 & 289 & 0.754 & 10.0 & 0.432 \\ 207 & 290 & 0.715 & 10.0 & 0.424 \\ 138 & 360 & 0.383 & 10.0 & 0.452 \\ 80 & 425 & 0.188 & 11.0 & 0.435 \\ 61 & 441 & 0.138 & 10.0 & 0.423 \\ 5.50 & 501 & 0.0101 & 10.0 & 0.150 \\ 5.00 & 491 & 0.0102 & 25.0 & 0.131 \\ 3.80 & 501 & 0.00780 & 17.0 & 0.107 \\ 2.25 & 496 & 0.00453 & 35.0 & 0.0720 \\ 1.35 & 497 & 0.00272 & 30.0 & 0.0500\end{array}$

Total Pressure 100 torr

$\begin{array}{rrrrr}96 & 22 & 4.36 & 15.0 & 0.200 \\ 97 & 23 & 4.22 & 10.0 & 0.245 \\ 67 & 30 & 2.23 & 35.0 & 0.293 \\ 67 & 30 & 2.23 & 4.00 & 0.276 \\ 117 & 64 & 1.83 & 30.0 & 0.143 \\ 49 & 60 & 0.818 & 10.0 & 0.364 \\ 38 & 68 & 0.599 & 5.00 & 0.372 \\ 50 & 125 & 0.400 & 5.00 & 0.397 \\ 24 & 88 & 0.272 & 81.0 & 0.416 \\ 18 & 89 & 0.203 & 10.0 & 0.397 \\ 9.90 & 104 & 0.0950 & 6.00 & 0.360 \\ 6.70 & 94.0 & 0.0715 & 10.0 & 0.359 \\ 5.4 & 103 & 0.0525 & 5.00 & 0.274 * \\ 4.70 & 99 & 0.0475 & 95.0 & 0.325 \\ 4.10 & 109 & 0.0376 & 10.0 & 0.295 \\ 2.65 & 105 & 0.0252 & 10.0 & 0.244 \\ 2.70 & 109 & 0.0247 & 30.0 & 0.234 \\ 1.50 & 99 & 0.0152 & 10.0 & 0.177 \\ 1.10 & 111 & 0.0099 & 10.0 & 0.135\end{array}$


TABLE II (Cont.)
$\left[\mathrm{O}_{2}\right]$, torr
[CO], torr
$\left[\mathrm{O}_{2}\right] /[\mathrm{CO}]$
Ir radiation
$\Phi\left\{\mathrm{CO}_{2}\right\}$

Total Pressure $\sim 50$ tor $r$

$\begin{array}{cclll}26.0 & 9.75 & 2.66 & 10.0 & 0.212 \\ 32.5 & 17.5 & 1.85 & 10.0 & 0.247 \\ 20 & 30 & 0.668 & 10.0 & 0.330 \\ 20 & 32 & 0.628 & 10.0 & 0.328 \\ 12 & 38 & 0.316 & 10.0 & 0.363 \\ 5.70 & 44 & 0.130 & 15.0 & 0.352 \\ 1.90 & 48 & 0.0396 & 25.0 & 0.246 \\ 1.05 & 49 & 0.0214 & 15.0 & 0.192\end{array}$

$\mathrm{a}_{\mathrm{a}}=4.57 \times 10^{-9} \frac{\text { Einsteins }}{\mathrm{cc}-\mathrm{min}}$ in all runs except those marked with an asterisk, when $I_{a}=0.252 \times 10^{-9} \frac{\text { Einsteins }}{\text { cc-sec }}$. 


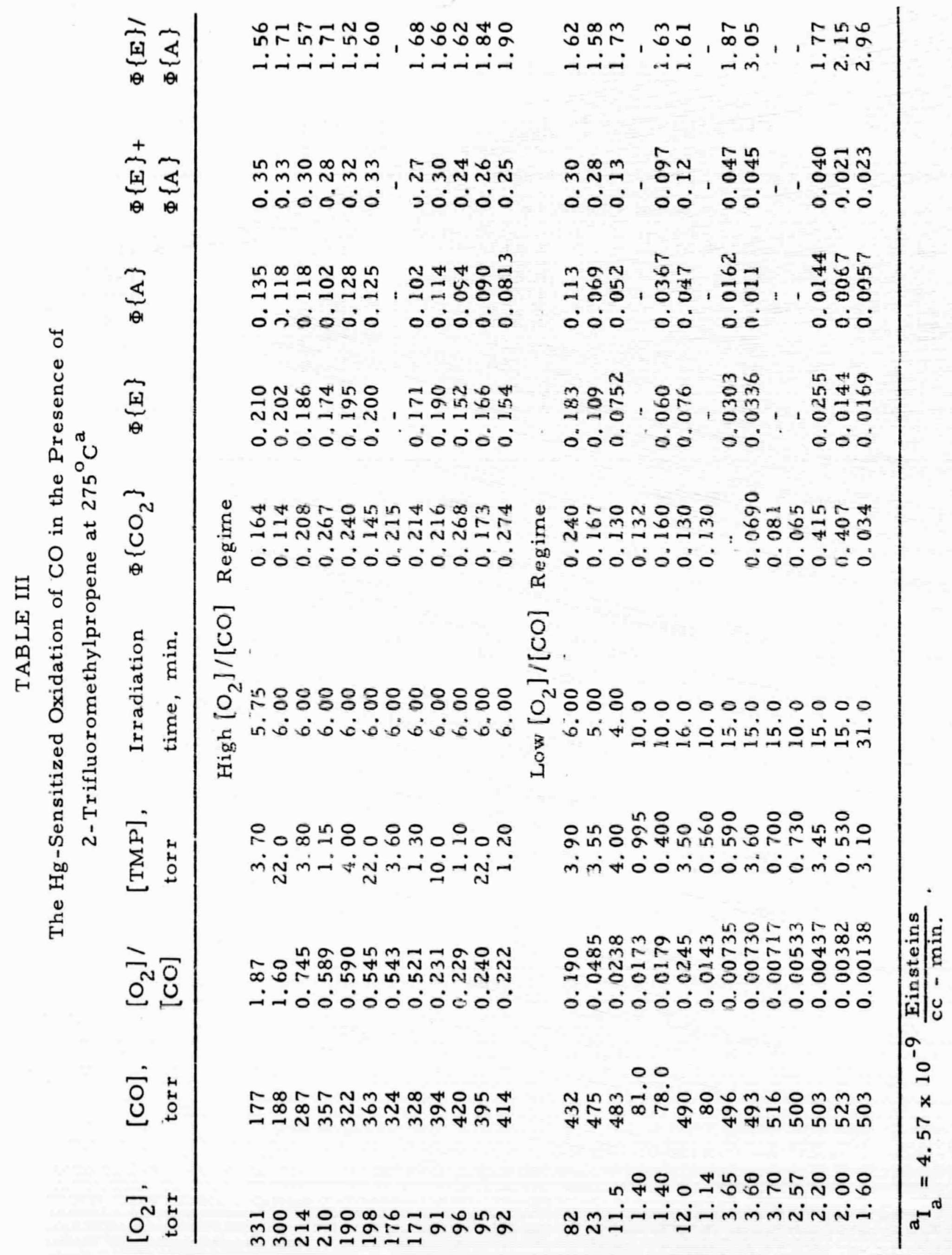




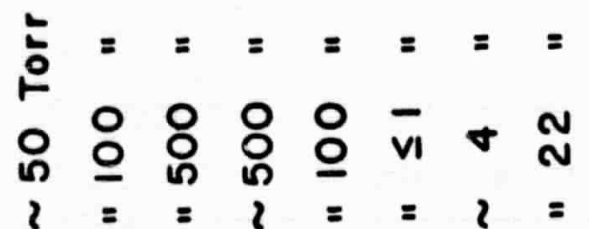

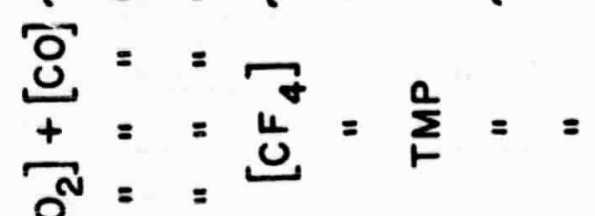

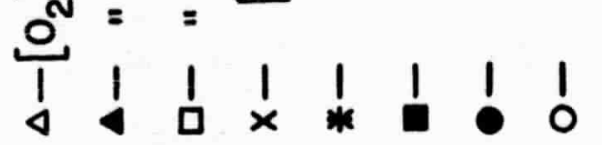

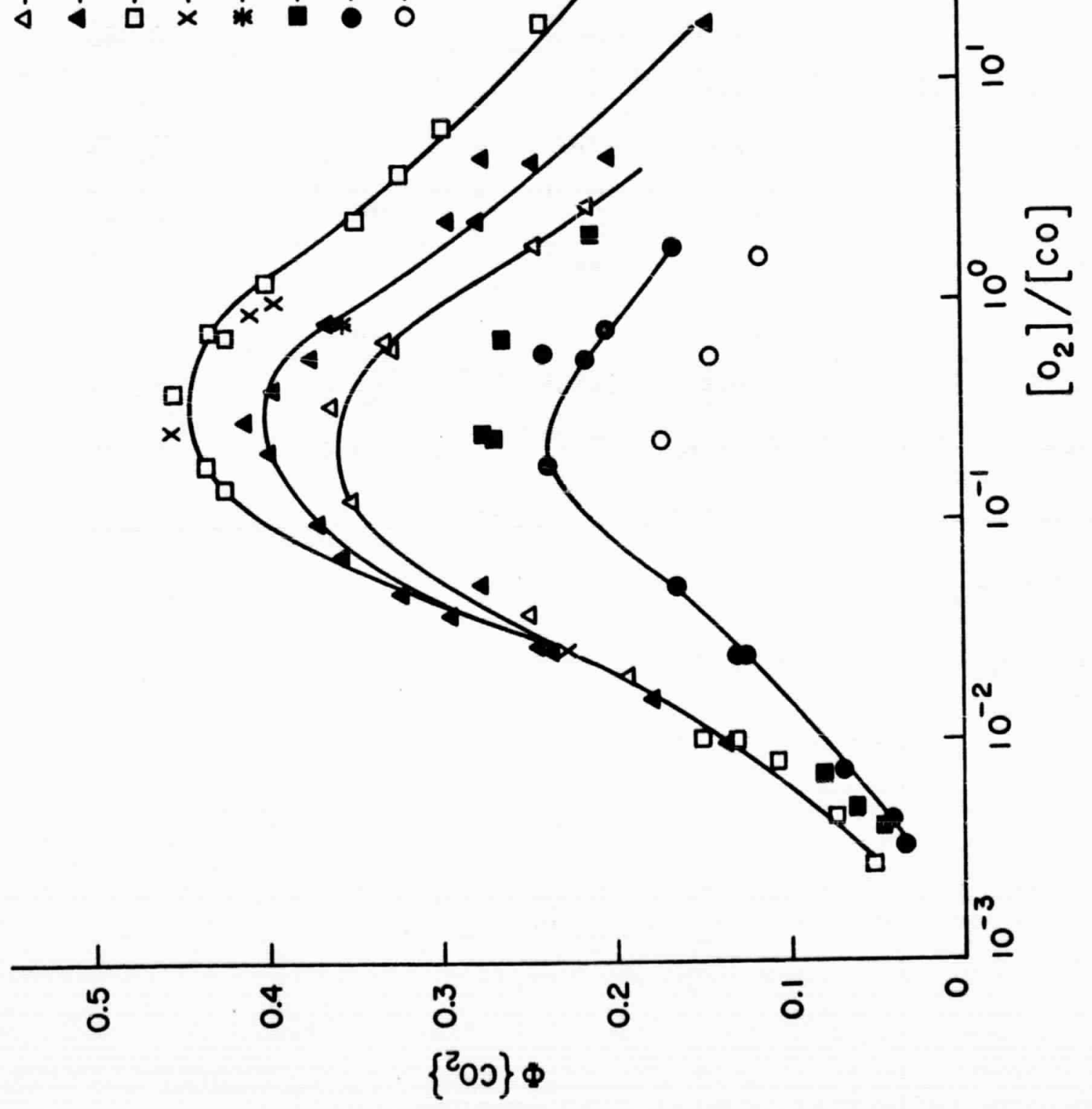


TABLE IV

The Hg-Sensitized Oxidation of $\mathrm{CO}$ in the Presence of $\mathrm{CF}_{4}$ and $\mathrm{N}_{2}$ at $275^{\circ} \mathrm{C}$

$\left[\mathrm{O}_{2}\right]$

[Co] ,

$\left[\mathrm{O}_{2}, \mathrm{O}\right.$

[x] ,

Irradiation

$\Phi\left\{\mathrm{CO}_{2}\right\}$

torr

[CO]

torr

time, min.

$\begin{array}{lcllll}50 & 53 & 0.945 & 418^{\mathrm{a}} & 20.0 & 0.392 \\ 27 & 30 & 0.900 & 441^{\mathrm{a}} & 22.0 & 0.410 \\ 24.5 & 31 & 0.790 & 96^{\mathrm{a}} & 20.0 & 0.354 \\ 11 & 41.5 & 0.265 & 482^{\mathrm{a}} & 21.0 & 0.455 \\ 2.60 & 100 & 0.026 & 411^{\mathrm{a}} & 20.25 & 0.226 \\ 68 & 34 & 2.00 & 600^{\mathrm{b}} & 20.0 & 0.320 \\ 65 & 36 & 1.80 & 614^{\mathrm{b}} & 10.0 & 0.324 \\ 33 & 18.5 & 1.78 & 663^{\mathrm{b}} & 20.0 & 0.290 \\ 20 & 31 & 0.646 & 664^{\mathrm{b}} & 20.0 & 0.310 \\ 2.75 & 97 & 0.0284 & 550^{\mathrm{b}} & 25.0 & 0.236 \\ 3.15 & 114 & 0.0276 & 523^{\mathrm{b}} & 30.0 & 0.220\end{array}$

${ }^{a} \mathrm{X}=\mathrm{CF}_{4}$

${ }^{b} \mathrm{x}=\mathrm{N}_{2}$ 
as when the other gases were used to raise the pressure. In two runs the intensity, $I_{a}$, was changed by a factor of 18 with no effect upon $\Phi\left\{\mathrm{CO}_{2}\right\}$. In the presence of TMP for $\left[\mathrm{O}_{2}\right] /[\mathrm{CO}]<0.08, \Phi\left\{\mathrm{CO}_{2}\right\}$ is reduced by about a factor of 2 and $\Phi\left\{\mathrm{CO}_{2}\right\}$ is close to $\Phi\{E\}+\Phi\{\mathrm{A}\}$ providing $[\mathrm{CO}] /[\mathrm{TMP}]<200$. For $[\mathrm{CO}] /[\mathrm{TMP}]>200, \Phi\left\{\mathrm{CO}_{2}\right\}>\Phi\{\mathrm{E}\}+$ $\Phi\{A\}$. The average value for $\Phi\{E\} / \Phi\{A\}=1.63$ for the rung of $\leq 10$ minutes duration. Within experimental errors this value is the same as that obtained for the reaction of $O$ atoms with TMP at $275^{\circ} \mathrm{C}$. A complication observed at $275^{\circ} \mathrm{C}$ is a thermal decomposition of the aldehyde to give some $\mathrm{CO}_{2}$. The last run in Tabie $\mathrm{V}$ illustrates this. In this run the contents of the cell were allowed to remain in the cell for 120 minutes after irradiation. $\Phi\left\{\mathrm{CO}_{2}\right\}$ increased by about a factor of 2 , whereas the aldehyde yield was reduced by $90 \%$. In most runs the contribution to $\Phi\left\{\mathrm{CO}_{2}\right\}$ due to the dark reaction is small, but it does account for the smaller yield of the aldehyde for longer duration runs. In the presence of TMP for $\left[\mathrm{O}_{2}\right] /[\mathrm{CO}]>0.08, \Phi\left\{\mathrm{CO}_{2}\right\}$ is also about a factor of 2 less than in the absence of TMP. $\Phi\left\{\mathrm{CO}_{2}\right\} \approx \Phi\{\mathrm{A}\}+$ $\Phi\{E\}$ if $[\mathrm{CO}] /[\mathrm{TMP}] \geq 350$ and $\Phi\left\{\mathrm{CO}_{2}\right\}<\Phi\{\mathrm{E}\}+\Phi\{\mathrm{A}\}$ for [CO]/[TMP]< 350.

The results for runs in the absence of $\mathrm{CO}$ at $275^{\circ} \mathrm{C}$ are presented in Table V. Except for the run in which the products were kept in the cell after irradiation there is no effect on $\Phi\left\{\mathrm{CO}_{2}\right\}, \Phi\{\mathrm{E}\}$, or $\Phi\{\mathrm{A}\}$ when $\left[\mathrm{O}_{2}\right] /[\mathrm{TMP}]$ was changed from $22-240 . \Phi\{\mathrm{E}\}+\Phi\{\mathrm{A}\}$ exceeds $\Phi\left\{\mathrm{CO}_{2}\right\}$ by about a factor of 10 and the average $\Phi\{\mathrm{E}\} / \Phi\{\mathrm{A}\}=1.56$. The value of 1.56 for $\Phi\{E\} / \Phi\{A\}$ at $275^{\circ} \mathrm{C}$ is the same as in the presence of $\mathrm{CO}$, unlike at $25^{\circ} \mathrm{C}$, and the same as for the reaction of $\mathrm{O}$ atoms with TMP. 
TABLE V

The Hg-Sensitized Oxidation of 2 -Trifluoromethylpropene at $275^{\circ} \mathrm{C}^{\mathrm{a}}$ $\left[\mathrm{O}_{2}\right], \quad[\mathrm{TMP}], \quad$ Irradiation $\Phi\left\{\mathrm{CO}_{2}\right\} \quad \Phi\{\mathrm{E}\} \quad \Phi\{\mathrm{A}\} \quad \Phi\{\mathrm{E}\}+\Phi\{\mathrm{E}\} /$ torr torr time, min. $\Phi\{\mathrm{A}\} \quad \Phi\{\mathrm{A}\}$

\begin{tabular}{lccccccc}
\hline 667 & 3.20 & 6.00 & 0.055 & 0.175 & 0.122 & 0.30 & 1.43 \\
343 & 4.50 & 6.00 & - & 0.178 & 0.121 & 0.30 & 1.47 \\
192 & 3.50 & 6.00 & - & 0.152 & 0.0985 & 0.25 & 1.54 \\
328 & 1.60 & 6.00 & 0.055 & 0.151 & - & - & - \\
118 & 3.70 & 6.00 & 0.053 & 0.159 & 0.092 & 0.25 & 1.72 \\
285 & 5.25 & 6.00 & 0.046 & 0.166 & 0.103 & 0.27 & 1.60 \\
266 & 1.10 & 6.00 & 0.048 & 0.157 & 0.099 & 0.27 & 1.59 \\
$273^{\mathrm{b}}$ & 1.50 & 6.00 & 0.117 & 0.157 & 0.0135 & 0.17 & 11.6 \\
\hline
\end{tabular}

$\mathrm{a}_{\mathrm{a}}=4.57 \times 10^{-9} \quad \frac{\text { Einsteins }}{\mathrm{cc}-\min }$

${ }^{b}$ After irradiation the cell contents remained in the cell for 120 minutes at $275^{\circ} \mathrm{C}$. 
TABLE VI

Relative Rate Constants for the Hg-Sensitized Oxidation of CO Rate Constant Ratio Value Temperature ${ }^{\circ} \mathrm{C}$ Source

\begin{tabular}{lcrl}
\hline $\mathrm{k}_{\mathrm{b}} / \mathrm{k}_{\mathrm{a}}$ & 1.08 & 275 & Eqn. I, Fig. 2 \\
$\mathrm{k}_{7} / \mathrm{k}_{6}$ & 1.2 & 25 & Eqn. I, Fig. 2 \\
& 2.4 & 275 & Eqn. VIII, Fig. 3 - no TMP \\
& 2.2 & 275 & Eqn. IX, Fig. 3 - TMP \\
$\mathrm{k}_{8} / \mathrm{k}_{6}$ & 2.2 & 275 & Eqn. X, Fig. 4 \\
& 23 & 25 & Eqn. IX, Fig. 5 \\
& 0.104 & 275 & Eqn. VIII, Fig. 3 - no TMP \\
& 0.085 & 275 & Eqn. IX, Fig. 3 - TMP \\
$\left(\mathrm{k}_{13}+\mathrm{k}_{14}\right) /\left(\mathrm{k}_{9}+\mathrm{k}_{12}\right)$ & 0.20 & 275 & Eqn. X, Fig. 4 \\
$\mathrm{k}_{14} / \mathrm{k}_{13}$ & 0.104 & 275 & Eqn. IX, Fig. 5 \\
$\mathrm{k}_{12} / \mathrm{k}_{9}$ & 12.0 & 275 & Eqn. XI, Fig. 6 \\
$\mathrm{k}_{11} / \mathrm{k}_{10}$ & 3.25 & 275 & Eqn. XI, Fig. 6 \\
$\mathrm{k}_{13} / \mathrm{k}_{9}$ & 25 torr & 275 & Eqn. XII, Fig. 7 \\
$\mathrm{k}_{14} / \mathrm{k}_{9}$ & 0.067 & 275 & \\
$\mathrm{k}_{12} / \mathrm{k}_{13}$ & 0.81 & 275 & \\
$\left(\mathrm{k}_{9}+\mathrm{k}_{12}\right) / \mathrm{k}_{21}$ & 55 & 275 & \\
$\left(\mathrm{k}_{13}+\mathrm{k}_{14}\right) / \mathrm{k}_{21}$ & 0.06 & 275 & Eqn. XIII, Table III \\
\hline
\end{tabular}


In order to be able to adjust [TMP] to prevent the quenching of $\mathrm{Hg}\left({ }^{3} \mathrm{P}_{1}\right)$ by TMP, it was necessary to know the quenching coefficient for $\mathrm{Hg}\left({ }^{3} \mathrm{P}_{1}\right)$ by TMP. This was determined at $25^{\circ} \mathrm{C}$ and $275^{\circ} \mathrm{C}$ by following the effect of [TMP] on $\mathrm{N}_{2}$ formation in the mercury sensitized decomposition of $\mathrm{N}_{2} \mathrm{O}-\mathrm{TMP}$ mixtures. The reaction scheme is

$$
\begin{aligned}
& \mathrm{Hg}\left({ }^{1} \mathrm{~S}_{0}\right)+\mathrm{hv} \rightarrow \mathrm{Hg}\left({ }^{3} \mathrm{P}_{1}\right) \\
& \left.\mathrm{Hg}\left({ }^{3} \mathrm{P}_{1}\right)+\mathrm{N}_{2} \mathrm{O} \rightarrow \mathrm{N}_{2}+\mathrm{O}+\mathrm{Hg}^{1}{ }^{1} \mathrm{~S}_{0}\right) \\
& \mathrm{Hg}\left({ }^{3} \mathrm{P}_{1}\right)+\mathrm{TMP} \rightarrow \mathrm{Hg}\left({ }^{1} \mathrm{~S}_{0}\right)+\mathrm{TMP}
\end{aligned}
$$

This scheme leads to

$$
\Phi\left\{\mathrm{N}_{2}\right\}^{-1}=1+\frac{\mathrm{k}_{\mathrm{b}}[\mathrm{TMP}]}{\mathrm{k}_{\mathrm{a}}\left[\mathrm{N}_{2} \mathrm{O}\right]}
$$

The data is presented in Figure 2 as a plot of $\Phi\left\{\mathrm{N}_{2}\right\}^{-1}$ vs. [TMP]/[N 20$]$. From the slopes $\mathrm{k}_{\mathrm{b}} / \mathrm{k}_{\mathrm{a}}=1.23$ at $25^{\circ} \mathrm{C}$ and $\mathrm{k}_{\mathrm{b}} / \mathrm{k}_{\mathrm{a}}=1.08$ at $275^{\circ} \mathrm{C}$, though these values are the same within the experimental uncertainty. For all the experiments with TMP added to the $\mathrm{O}_{2}$ or $\mathrm{CO}-\mathrm{O}_{2}$ mixtures, [TMP] was kept sufficiently small so that reaction b was ne gligible. 


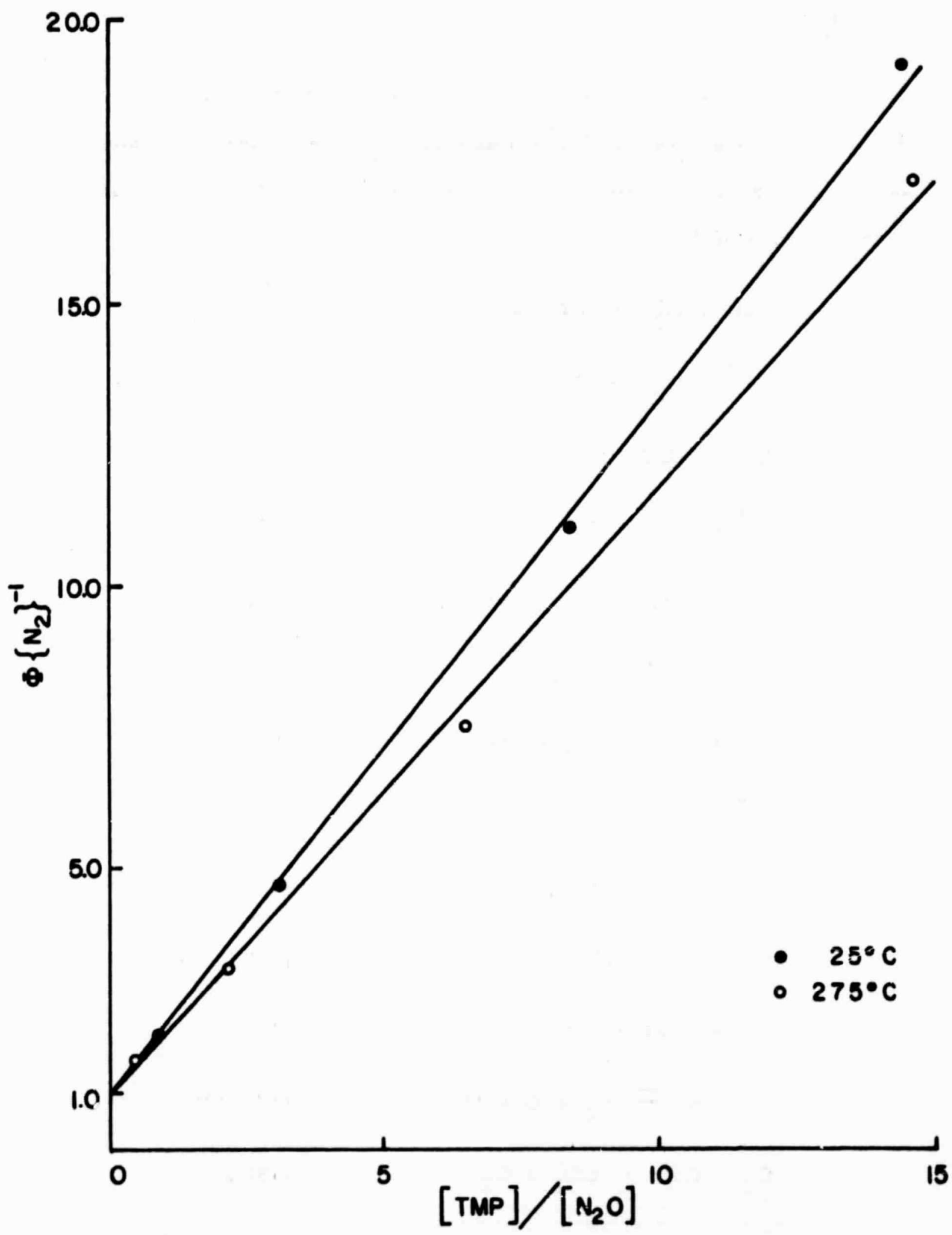

Figure 2 
$-20-$

$\underline{\text { DISCUSSION }}$

The initial steps in the $\mathrm{Hg}$-sensitized oxidation of $\mathrm{CO}$ will be all the reactions deactivating $\left.\mathrm{Hg}^{3} \mathrm{P}_{1}\right)$ and $\mathrm{Hg}\left({ }^{3} \mathrm{P}_{0}\right)$, reactions $1-5$. The subsequent reactions proposed to account for the results at $275^{\circ} \mathrm{C}$ and in the absence of TMP are the following:

$$
\begin{aligned}
& \mathrm{CO}^{\dagger}+\mathrm{O}_{2} \rightarrow \mathrm{CO}_{2}+\mathrm{O} \\
& \mathrm{CO}^{\dagger}+\mathrm{O}_{2} \rightarrow \mathrm{CO}+\mathrm{O}_{2} \\
& \mathrm{co}^{\dagger}+\mathrm{CO} \rightarrow 2 \mathrm{CO} \\
& \mathrm{O}_{2}^{*}+\mathrm{CO} \rightarrow \mathrm{CO}_{3} \\
& \mathrm{CO}_{3}+\mathrm{M} \rightarrow \mathrm{CO}_{2}+\mathrm{O}+\mathrm{M} \\
& \mathrm{CO}_{3} \rightarrow \mathrm{CO}+\mathrm{O}_{2} \\
& \mathrm{O}_{2}^{*}+\mathrm{CO} \rightarrow \mathrm{O}_{2}+\mathrm{CO} \\
& \mathrm{O}_{2}^{*}+\mathrm{O}_{2} \rightarrow \mathrm{O}_{3}+\mathrm{O} \\
& \mathrm{O}_{2}^{*}+\mathrm{O}_{2} \rightarrow 2 \mathrm{O}_{2} \\
& \mathrm{O}+\mathrm{CO} \rightarrow \mathrm{CO}_{2} \\
& \mathrm{O}_{3}+\mathrm{M} \rightleftarrows \mathrm{O}_{2}+\mathrm{O}+\mathrm{M} \\
& \mathrm{O}_{3}+\mathrm{CO} \rightarrow \mathrm{CO}_{2}+\mathrm{O}_{2} \\
& \mathrm{O}_{3}+\mathrm{O} \rightarrow 2 \mathrm{O}_{2}
\end{aligned}
$$


The asterisk indicates electronically excited $\mathrm{O}_{2}$ and the dagger indicates vibrationally excited $\mathrm{CO}$ having sufficient energy to be able to undergo reaction 6 . The $\mathrm{O}_{2}^{*}$ produced in reactions 1 and 2 may not be the same, but the concentration of the state produced in the latter reaction will usually be unimportant compared to that produced in reaction 1 . From the scheme comprising reactions $1-5$, the fraction of $\mathrm{O}_{2}^{*}$ produced by reaction $l$ is given by

$$
\frac{\mathrm{R}\{1\}}{\mathrm{R}\{1\}+\mathrm{R}\{2\}}=\frac{1+\mathrm{k}_{4}[\mathrm{CO}] / \mathrm{k}_{2}\left[\mathrm{O}_{2}\right]}{1+\left(\mathrm{k}_{4} / \mathrm{k}_{2}+\mathrm{k}_{5} / \mathrm{k}_{1}\right)[\mathrm{CO}] /\left[\mathrm{O}_{2}\right]}
$$

The ratios $k_{1} /\left(k_{3}+k_{5}\right)$ and $k_{4} / k_{2}$ are 3.41 and 0.40 , respectively. 12 Since $\mathrm{k}_{5} /\left(\mathrm{k}_{3}+\mathrm{k}_{5}\right)$ is $\hat{\mathrm{v}} .78,6$ it cair be computed that the minimum value of $R\{1\} /(R\{1\}+R\{2\})$, i. e. when $\left[\mathrm{O}_{2}\right] /[\mathrm{CO}] \rightarrow 0$, is 0.64 . Under conditions where the reactions of $\mathrm{O}_{2}^{*}$ become important, i.e. $\left[\mathrm{O}_{2}\right] /[\mathrm{CO}] \sim$ 0.2 (see below), $R\{1\} /(R\{1\}+R\{2\}$ ) will be 0.72 and will increase as $\left[\mathrm{O}_{2}\right] /[\mathrm{CO}]$ increases.

Reaction 6 is postulated here for the first time. Reaction 8 is simply a collisional deactivation of the excited $\mathrm{CO}$, but reaction 7 is probably a sum of coilisional deactivation and deactivation via the same intermediate or transition state as in reaction 6 . Reaction 9 has not been previously postulated, but the quenching of $\mathrm{O}_{2}^{*}$ by $\mathrm{CO}$ has been studied. ${ }^{2}$ Presumably the intermediate to product formation is assymmetric $\mathrm{CO}_{3}$. This species may be different than the symmetric $\mathrm{CO}_{3}$ which is formed in the $\left.\mathrm{O}^{1} \mathrm{D}\right)+\mathrm{CO}_{2}$ system at high pressures ${ }^{8}$ and whose low semperature infrared spectrum has been obtained. ${ }^{13,14}$ Reaction 10 is a pressure induced dissociation of $\mathrm{CO}_{3}$. The pressure dependence is needed to account for the pressure effect shown in Figure 1. Reactions 11 and 12 comprise the deactivation of $\mathrm{O}_{2}^{*}$ by $\mathrm{CO}$ through the $\mathrm{CO}_{3}$ 
intermediate and by collisional quenching, respectively. Reactions 13 and 14, together with their relative importance, have been previousiy observed. ${ }^{1}$ The $\mathrm{O}_{3}$ formed in reaction 13 will be unstable at $275^{\circ} \mathrm{C}$ and will readily decompose according to reaction 17 , or it may also react with $\mathrm{CO}$ to give $\mathrm{CO}_{2}$, reaction 18 . Reaction 18 has been proposed from time to time, though the evidence indicates that this reaction is unimportant even at $275^{\circ} \mathrm{C} .{ }^{15}$ At higher [CO]/[O $\left.\mathrm{O}_{2}\right]$ the oxygen atoms will react with $\mathrm{CO}$ to give $\mathrm{CO}_{2}$, but as the $[\mathrm{CO}] /\left[\mathrm{O}_{2}\right]$ decreases the $\mathrm{O}$ atoms must eventually be lost by either reaction 16 or 19 or both. Reaction 16 has been shown to occur in a quartz reaction vessel. 16 Reaction 19 is well known at room temperature and will certainly occur at higher temperatures if the $\left[\mathrm{O}_{3}\right]$ is sufficiently high for its rate to compete with the rate of reaction 16 .

Reactions $6-19$ are the most reasonable reactions consistent with the experimental data. Other reasonable reactions will be discussed later and demonstrated to be unimportant.

In the presence of TMP the additional reactions that need to be considered are

$$
\begin{aligned}
& \mathrm{O}+\mathrm{TMP} \rightarrow \alpha \mathrm{E}+(1-a) \mathrm{A} \\
& \mathrm{O}_{2}^{*}+\mathrm{TMP} \rightarrow a \mathrm{CO}_{2}+\mathrm{bE}+\mathrm{cA}
\end{aligned}
$$

where $\alpha$ is the fraction of oxygen atoms that give $E(i . e, \alpha=0.60$ ), and $a, b, c$ are undetermined coefficients. Only a limited range of experimental conditions was accessible at room temperature, so that only the partial mechanism consisting of reactions $1-8,20$ and 21 need be considered. 
The reaction of $\mathrm{O}_{2}^{*}$ with some perfluorinated olefins has been studied, and it has been concluded that the reaction proceeds via excited olefin ${ }^{3}$

$$
\begin{aligned}
& \mathrm{O}_{2}^{*}+\text { Olefin } \rightarrow \mathrm{O}_{2}+(\text { Olefin })^{*} \\
& \mathrm{O}_{2}+(\text { Olefin })^{*} \rightarrow \text { Products. }
\end{aligned}
$$

This may also be the case for TMP, but our data is insuificient to show this. The formation of the aldehyde and epoxide in the absence of $\mathrm{CO}$ at $275^{\circ} \mathrm{C}$ in the same ratio as is obtained in the reaction of oxygen atoms with TMP (Table $V$ ) would suggest that oxygen atoms are also involved in the $\mathrm{O}_{2}$-TMP system. Atoms could be formed either via reaction 13 or 22

$$
\mathrm{O}_{2}^{*}+\mathrm{M} \rightarrow 2 \mathrm{O}+\mathrm{M}
$$

The fact that $\Phi\{\mathrm{E}\}$ and $\Phi\{\mathrm{A}\}$ are independent of $\left[\mathrm{O}_{2}\right] /[\mathrm{TMP}]$ and the fact that $>80 \%$ of all $\mathrm{O}_{2}^{*}$ react with TMP $\left[\left(\mathrm{k}_{13}+\mathrm{k}_{14}\right) / \mathrm{k}_{21} \sim 0.01\right.$ as determined later] argues against the formation of these products from oxygen atoms produced in reaction 13. Reaction 22 cannot be important either, because $\Phi\{\mathrm{E}\}$ and $\Phi\{\mathrm{A}\}$ are independent of $\left[\mathrm{O}_{2}\right] /[\mathrm{TMP}]$, and $\Phi\{\mathrm{E}\}+\Phi\{\mathrm{A}\} \ll 2$. An aiternative explanation is that reactions 20 and 21 at $275^{\circ} \mathrm{C}$ proceed via a common biradical intermediate such as suggested for the reaction of oxygen atoms with TMP, ${ }^{9}$ the reaction scheme being the following:

$$
\begin{aligned}
& \mathrm{O}_{2}+\text { Olefin } \rightarrow \cdot \mathrm{C}-\mathrm{C}-\mathrm{O}-\mathrm{O} . \\
& \mathrm{C}-\mathrm{C}-\mathrm{O}-\mathrm{O} \cdot+\mathrm{Olefin} \rightarrow \overrightarrow{275^{\circ} \mathrm{C}} \\
& \mathrm{O}+\text { Olefin } \rightarrow \cdot \mathrm{C}-\mathrm{C}-\mathrm{O} \cdot \rightarrow \alpha \mathrm{E}+(1-\alpha) \mathrm{A}
\end{aligned}
$$


At the elevated temperature the $\mathrm{O}-\mathrm{O}$ bond rupture of the peroxide intermediate occurs prior to reaction and the products are the same as from the $\mathrm{O}$ atom addition. At room temperature incipient product formation from the peroxide intermediate occure prior to complete 0 - $O$ bond rupture because of the smaller energy, and $\Phi\{\mathrm{E}\} / \Phi\{\mathrm{A}\}$ is not the same as for O-atom addition.

The application of the steady-state hypothesis to the mechanism consisting of reactions 1-19 leads to the following expression for $\Phi\left\{\mathrm{CO}_{2}\right\}$ in the absence of TMP

$$
\$\left\{\mathrm{CO}_{2}\right\}+(\mathrm{R}\{16\}+2 \mathrm{R}\{19\}) / I_{a}=f^{\prime} \Phi^{\prime}+f^{\prime \prime} \Phi^{\prime \prime}
$$

where $R\{16\}$ and $R\{19\}$ are the rates of reactions 16 and 19 , respectively, $f^{\prime}$ is the fraction of the radiation which produces $\mathrm{CO}^{\dagger}, f^{\prime \prime}$ is the fraction of the radiation that produces $O_{2}^{*}$ (note that $f^{\prime}+f^{\prime \prime}=1$ ), $\Phi^{\prime}$ is the fraction of the $\mathrm{CO}^{\dagger}$ produced that yields products, and $\Phi^{\prime \prime}$ is the fraction of the $\mathrm{O}_{2}^{*}$ produced that yields products. The specific expressions for the four terms on the right-hand side of Equation II are

$$
\begin{aligned}
f^{\prime} & =\frac{[C C]\left\{k_{3}+k_{4} k_{5}[\mathrm{CO}] /\left(k_{2}\left[O_{2}\right]+k_{4}[\mathrm{CO}]\right)\right\}}{k_{1}\left[O_{2}\right]+\left(k_{3}+k_{5}\right)[C O]} \\
f^{\prime \prime} & =\frac{\left[O_{2}\right]\left\{k_{1}+k_{2} k_{5}[\mathrm{CO}] /\left(k_{2}\left[O_{2}\right]+k_{4}[\mathrm{CO}]\right)\right\}}{k_{1}\left[O_{2}\right]+\left(k_{3}+k_{5}\right)[\mathrm{CO}]} \\
\Phi^{\prime} & =2 k_{6}\left[O_{2}\right] /\left\{\left(k_{6}+k_{7}\right)\left[O_{2}\right]+k_{8}[\mathrm{CO}]\right\} \\
\Phi^{\prime \prime} & =\frac{2 p k_{9}[\mathrm{CO}]+2 k_{13}\left[O_{2}\right]}{\left(k_{9}+k_{12}\right)[\mathrm{CO}]+\left(k_{13}+k_{14}\right)\left[O_{2}\right]}
\end{aligned}
$$


where $\beta \equiv k_{10}[M] /\left(k_{10}[M]+k_{11}\right)$.

VII

Equation II is a complex function of the reactant pressures, but depends primarily on the $\left[\mathrm{O}_{2}\right] /[\mathrm{CO}]$ ratio. For the evaluation of rate constants, it is convenient to divide the range of $\left[\mathrm{O}_{2}\right] /[\mathrm{CO}]$ ratios into a high $\left[\mathrm{O}_{2}\right] /[\mathrm{CO}]$ regime and a low $\left[\mathrm{O}_{2}\right] /[\mathrm{CO}]$ regime.

\section{Low $\left[\mathrm{C}_{2}\right] /[\mathrm{CO}]$ Regime}

We as sume that steps $9=14,16$ and 19 are unimportant at low $\left[\mathrm{O}_{2}\right] /[\mathrm{CO}]$. Under these conditions, expression II reduces to

$$
f^{\prime} \Phi\left\{\mathrm{CO}_{2}\right\}^{-1}=\left(\Phi^{\prime}\right)^{-1}=\frac{1}{2}\left(1+\frac{k_{7}}{k_{6}}+\frac{k_{8}}{k_{6}} \frac{[\mathrm{CO}]}{\left[\mathrm{O}_{2}\right]}\right)
$$

A plot of the left-hand side of Equation VIII vs. [CO] $/\left[\mathrm{O}_{2}\right]$ should be linear with the intercept equal to $(1 / 2)\left(1+k_{7} / k_{6}\right)$ and the slope equal to $k_{8} / 2 k_{6^{\circ}}$. Values of $f^{\prime}$ were calculated from the known quenching rate constants of $\left.\mathrm{Hg}^{3}{ }^{3} \mathrm{P}_{1}\right)$ and $\mathrm{Hg}\left({ }^{3} \mathrm{P}_{0}\right)$ by $\mathrm{CO}$ and $\mathrm{O}_{2}$. These values are: $k_{1} /\left(k_{3}+k_{5}\right)=3.41,{ }^{12} k_{4} / k_{2}=0.40,{ }^{12}$ and $k_{5} /\left(k_{3}+k_{5}\right)=0.78 .^{6}$ Figure 3 presents the plot of the experimental data in accordance with expression VIII. The plot is linear for $[\mathrm{CO}] /\left[\mathrm{O}_{2}\right]>20$, but as $[\mathrm{CO}] /\left[\mathrm{O}_{2}\right]$ drops below 20 the slope changes sharply. Thus, the assumption that reactions $9-14,16$ and 19 are negligible breaks down at $[\mathrm{CO}] /\left[\mathrm{O}_{2}\right]=20$. The slope of the linear portion of the line gives $k_{8} / k_{6}=0.104$ and the intercept gives $k_{7} / k_{6}=2.4$.

The experiments in the presence of TMP at $\operatorname{low}\left[\mathrm{O}_{2}\right] /[\mathrm{CO}]$ ratios demonstrate the formation of oxygen atoms. First of all, both the epoxide and aldehyde are formed in the same ratio as in the O-TMP system. This in itself is not sufficient evidence, since reaction 21 also gives the same products in the same ratio. Howevis, the quantum 


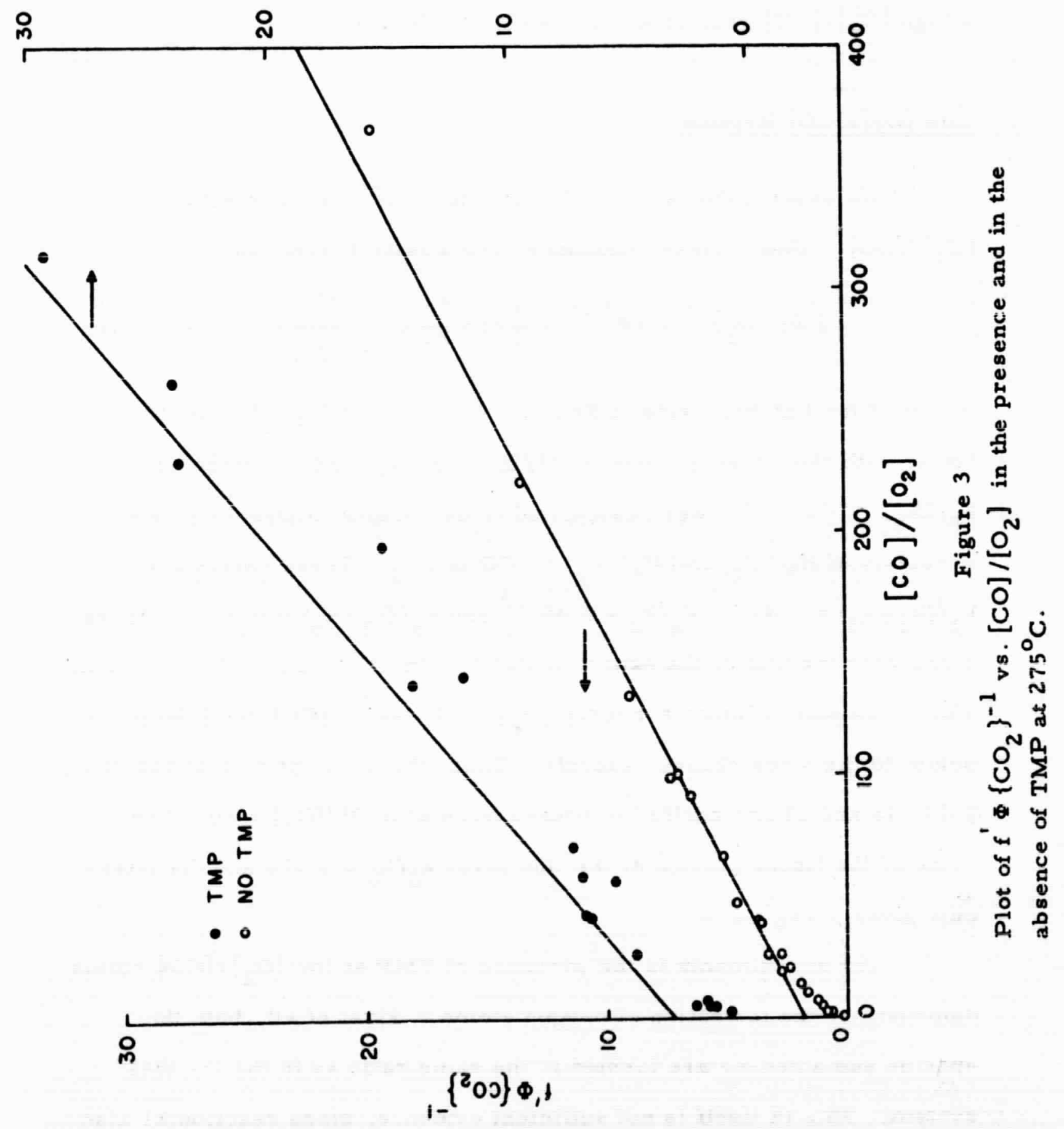


yields are at least a factor of 10 too large to be explained by reaction 21. Secondly $\Phi\left\{\mathrm{CO}_{2}\right\}$ depends on the [CO]/[TMP] ratio as predicted from the known relative constants for the reaction of $\mathrm{O}$ atoms with $\mathrm{CO}$ and TMP. 10

The mechanism predicts that in the presence of TMP under conditions where all the oxygen atoms are scavenged that $\Phi\left\{\mathrm{CO}_{2}\right\}$ be reduced by a factor of 2 and that $\Phi\left\{\mathrm{CO}_{2}\right\}=\Phi\{\mathrm{E}\}+\Phi\{\mathrm{A}\}$. Examination of Figure 1 shows that for high $[\mathrm{CO}] /\left[\mathrm{O}_{2}\right]$ ratios and for $[\mathrm{CO}] /[\mathrm{TMP}]<$ 150, $\Phi\left\{\mathrm{CO}_{2}\right\}$ is reduced by about a factor of 2 and examination of Table III shows that for high $[\mathrm{CO}] /\left[\mathrm{O}_{2}\right]$ and for [CO]/[TMP]<150, $\Phi\left\{\mathrm{CO}_{2}\right\} \approx$ $\Phi\{E\}+\Phi\{A\}$. The expression which applies in the presence of TMP is

$$
f^{\prime} \Phi\left\{\mathrm{CO}_{2}\right\}^{-1}=1+\mathrm{k}_{7} / \mathrm{k}_{6}+\mathrm{k}_{8}[\mathrm{CO}] / \mathrm{k}_{6}\left[\mathrm{O}_{2}\right]
$$

IX

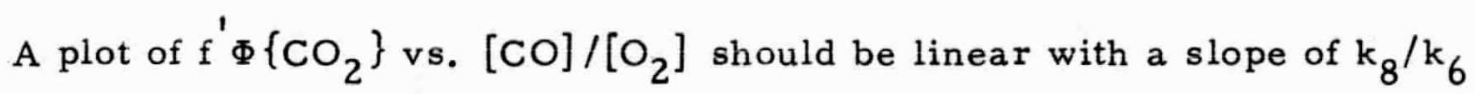
and an intercept of $1+k_{7} / k_{6}$. This plot also is shown in Figure 3. The plot is reasonably linear for $[\mathrm{CO}] /\left[\mathrm{O}_{2}\right]>20$, but the slope changes as [CO $/\left[\mathrm{O}_{2}\right]$ drops below 20 , because the reactions of $\mathrm{O}_{2}^{*}$ with $\mathrm{CO}$ and $\mathrm{O}_{2}$ become important, The points for $[\mathrm{CO}] /\left[\mathrm{O}_{2}\right]<20$ and for larger [CO]/[TMP] ratios (runs with $\sim 1$ torr TMP, Table III) lie lower thar those at lower [CO]/[TMP] ratios (runs with 4-22 torr TMP). The reason for this being that at lower [CO]/[TMP] reaction 21 becomes important. in the linear portion the points for which [CO]/[TMP] $>500$ lie below the line, because not all the $O$ atoms are scavenged by TMP, as a calculation using the known relative rate constants ${ }^{10}$ for reactions 15 and 20 indicates. The slope and intercept give, respectively, $k_{8} / k_{6}=$ 0.085 and $\mathrm{k}_{7} / \mathrm{k}_{6}=2.2$. 
Since $\Phi\left\{\mathrm{CO}_{2}\right\}=\Phi\{\mathrm{E}\}+\Phi\{\mathrm{A}\}$ and since $\Phi\{\mathrm{E}\} / \Phi\{\mathrm{A}\}=1$. 5, a plot of either $f^{\prime}(\Phi\{E\}+\Phi\{A\})^{-1}$ or $f^{\prime} \Phi\{E\}^{-1}$ vs. [CO]/[O $]$ also should be linear for $[\mathrm{CO}] /\left[\mathrm{O}_{2}\right] \geq 2.0$. Figure 4 is a plot of $\mathrm{f}^{\prime} \Phi\{\mathrm{E}\}^{-1}$ vs. [CO]/ $\left[\mathrm{O}_{2}\right]$, and it should fit the expression

$$
f^{\prime} \Phi\{E\}^{-1}=1.67\left(1+k_{7} / k_{6}\right)+1.67 k_{8}[\mathrm{CO}] / k_{6}\left[O_{2}\right]
$$

A plot involving $\Phi\{E\}+\Phi\{A\}$ is not shown because some of the aldehyde decomposed, thus making the measured values of $\Phi\{A\}$ somewhat lower than they should be. The slopes and intercept of Figure 4 give, respectively, $\mathrm{k}_{8} / \mathrm{k}_{6}=0.104$ and $\mathrm{k}_{7} / \mathrm{k}_{6}=2.2$.

The addition of excess $\mathrm{N}_{2}$ or $\mathrm{CF}_{4}$ in the low $\left[\mathrm{O}_{2}\right] /[\mathrm{CO}]$ regime has no effect upon $\Phi\left\{\mathrm{CO}_{2}\right\}$. Both $\mathrm{N}_{2}$ and $\mathrm{CF}_{4}$ are very poor quenchers of $\mathrm{Hg}^{3} \mathrm{Py},{ }^{12,17}$ but it is somewhat surprising that they are also such poor quenchers of $\mathrm{CO}^{\dagger}$. Thus our results show that $\mathrm{O}_{2}$ is much more effective than $\mathrm{CO}$, which in turn is much more effective than $\mathrm{N}_{2}$ and $\mathrm{CF}_{4}$ in removing $\mathrm{CO}^{\dagger}$. Foster and Kimbell ${ }^{18}$ have shown that $\mathrm{N}_{2}$ can remove low vibrational levels of $\mathrm{CO}$, but it is relatively inefficient in depopulating levels for $v \sim 9$. Consequently $\mathrm{CO}^{\dagger}$ must represent the higher vibrational levels ( $\sim$ 9) of $\mathrm{CO}$.

At room temperature the upper value for $\left[\mathrm{O}_{2}\right] /[\mathrm{CO}]$ was limited to 0.19 , because of the requirements that $\left[\mathrm{O}_{2}\right] /[\mathrm{TMP}]<5$ and $\left(\left[\mathrm{O}_{2}\right]+\right.$ $0.29[\mathrm{CO}] / /[\mathrm{TMP}]>10$. The mechanism predicts that if oxygen atoms are produced in reaction 6 then $\Phi\{\mathrm{E}\} / \Phi\{\mathrm{A}\}=1.50$ and, if complete scavenging occurs, $\Phi\left\{\mathrm{CO}_{2}\right\}=\Phi\{\mathrm{E}\}+\Phi\{\mathrm{A}\}$. The data in Table I show that this is approximately the case for the second condition and that the average value of $\Phi\{E\} / \Phi\{A\}=1.50$. The small difference between $\Phi\left\{\mathrm{CO}_{2}\right\}$ and $\Phi\{\mathrm{E}\}+\Phi\{\mathrm{A}\}$ in some of the runs can be explained by 


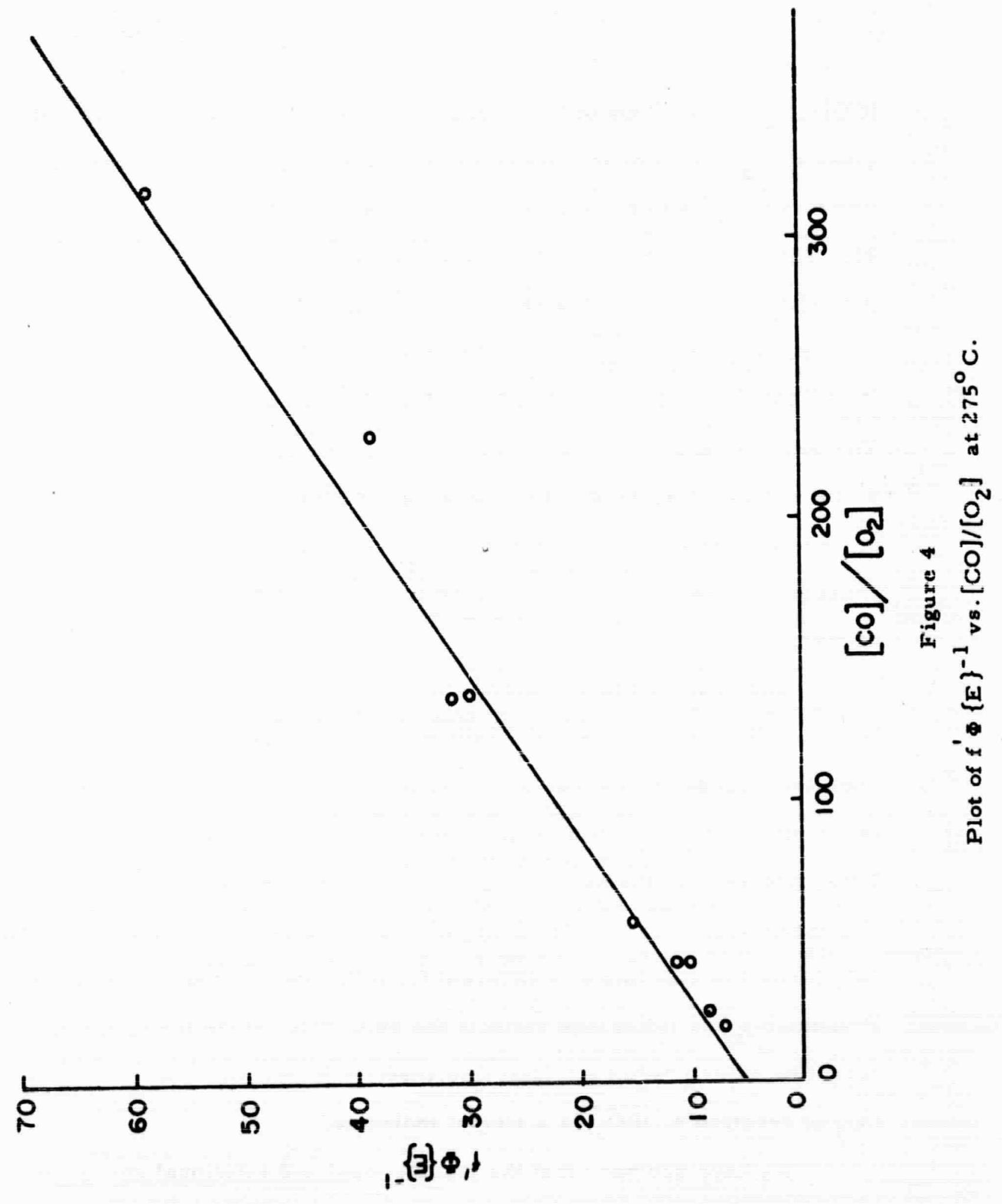


incomplete scavenging of the oxygen atoms, the extent of ecavenging being just about what is expected from the known value for $k_{20} / k_{15}$ at room temperature. ${ }^{10}$ Figure 5 presents a plot of $\mathrm{f}^{\prime} \cdot\left\{\mathrm{CO}_{2}\right\}^{-1}$ ve. [CO] $/\left[\mathrm{U}_{2}\right]$. The lope of this plot gives $k_{8} / k_{6}=0.24$ and the intercept gives $k_{i} / k_{6} \sim 3$. For the run at the lowest $[\mathrm{CO}] /\left[\mathrm{O}_{2}\right]$ a amall correc tion to $\$\left(\mathrm{CO}_{2}\right\}$ was made to accoust for the contribution from reaction 21. The line in Figure 5 indicates no curvature even at the lowest [CO] $/\left[\mathrm{O}_{2}\right]$, contrary to the results at $275^{\circ} \mathrm{C}$. This is reasonable because $\left(k_{14}+k_{13}\right) / k_{21}$ will be shown to be 0.012 at $275^{\circ} \mathrm{C}$, and since [O $\left.\mathrm{O}_{2}\right] /\left[\right.$ TMP] $\lesssim 5.0$, more than $90 \%$ of the $\mathrm{O}_{2}^{*}$ will be scavenged by TMP. The pointe with 19,4, 21.2, and 24 torr $\mathrm{O}_{2}$, the dark points in Figure 5, lie somewhat above the line, because for these runs $\left[\mathrm{O}_{2}\right] /[\mathrm{TMP}] \geq$ 5, and the time of irradiation for two of these runs was relatively long; consequently some $\mathrm{O}_{3}$, and therefore some $\mathrm{HgO}$, formation may have occurred.

The observed temperature effect on $k_{8} / k_{6}$, but not on $k_{7} / k_{6}$, indicates that reactions 6 and 7 have equal and probabiy omall activation energies. An activation energy for reaction 8 is not expected sincs it is simply a coliisional deactivation of $\mathrm{CO}^{\dagger}$. On the other hand reaction 7 may proceed via the same complex or transition state as reaction 6 . The independesce of reaction 6 on [M] clearly shows that the intermediate $\mathrm{CO}_{3}$ formed in reaction 6 is different from the one formed in reaction 9. Presumably this difference reflects the opin state, oince the opin conservation rules predict a triplet intermediate in reaction 6 but a einglet $\mathrm{CO}_{3}$ in reaction 9, if $\mathrm{O}_{2}^{*}$ is a ainglet molecule.

We have assumed that the translational and rotational energy of the initially produced $\mathrm{CO}$ in reactions 3 and 4 is rapidly lost and that the 


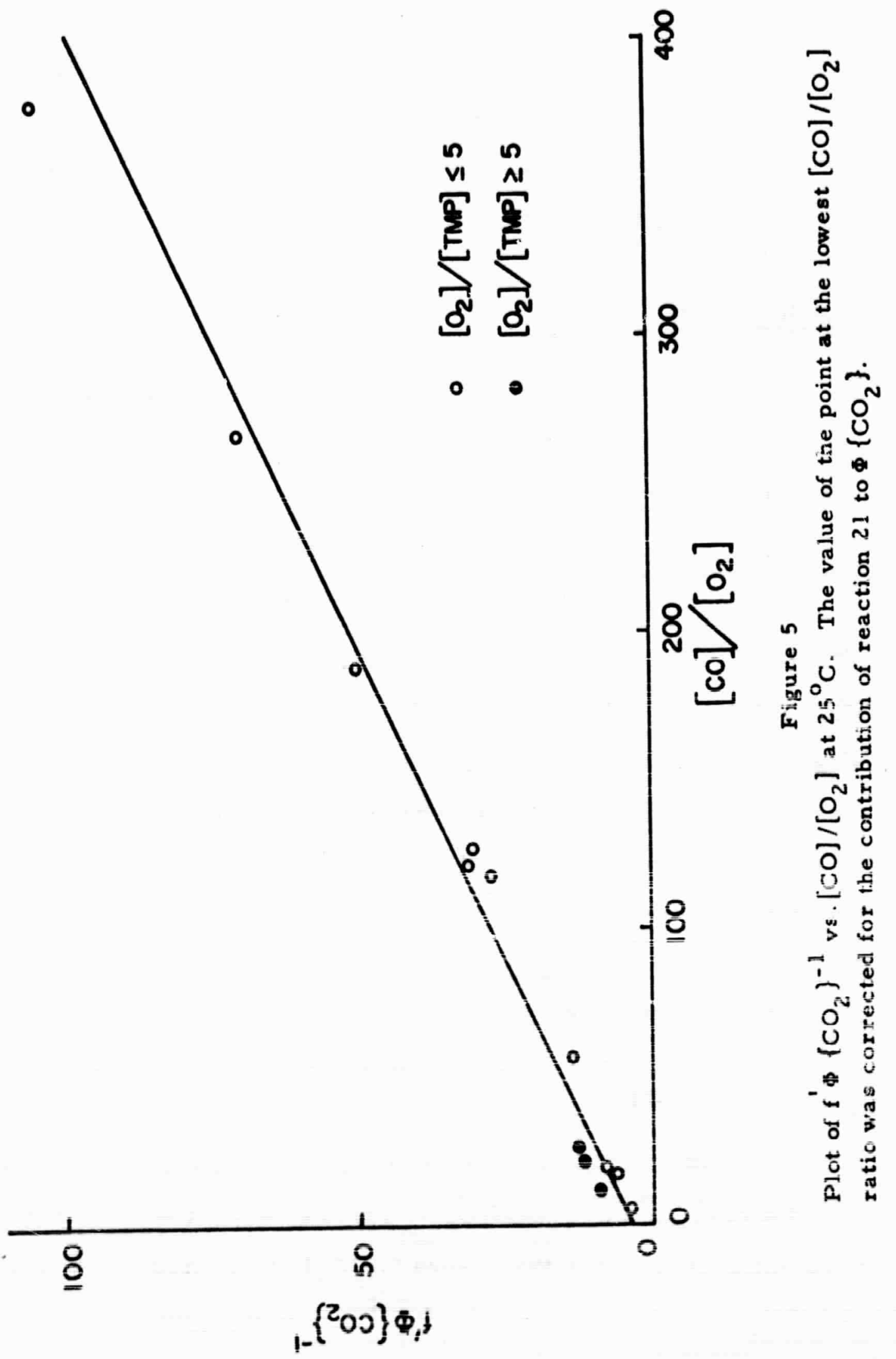


reactive species in reactions $6-8$ is vibrationally excited 60 . The

results support this assumption, since the value for $\left(k_{6}+k_{7}\right) / k_{8}=13-50$ is much too large to be consistent with reaction 8 being translational or rotational energy quenching Further support comes from the fact that both $\mathrm{N}_{2}$ and $\mathrm{CF}_{4}$ are inefficient quenchers of $\mathrm{CO}^{\dagger}$.

\section{Figh $\left[\mathrm{O}_{2}\right] /[\mathrm{CO}]$ Regime}

We assume that all reactions of $\mathrm{O}_{2}^{*}$ are important, but that all $\mathrm{O}_{3}$ or oxygen atoms react to give $\mathrm{CO}_{2}$, i. e. reactions 16 and 19 are negligible. Then Equation il can be rearranged to

$$
2 f^{\prime \prime}\left(\Phi\left\{\mathrm{CO}_{2}\right\}-\mathrm{f}^{\prime} \Phi^{\prime}\right)^{-1}=2\left(\Phi^{\prime \prime}\right)^{-1}=\frac{1+\mathrm{k}_{12} / \mathrm{k}_{9}+\left(\mathrm{k}_{13}+\mathrm{k}_{14}\right)\left[\mathrm{O}_{2}\right] / \mathrm{k}_{9}[\mathrm{CO}]}{\beta+\mathrm{k}_{13}\left[\mathrm{O}_{2}\right] / \mathrm{k}_{9}[\mathrm{CO}]} \times \mathrm{I}
$$

The left-hand side of Equation XI can be computed from the known quenching constants for $\left.\mathrm{Hg}^{3} \mathrm{P}_{1}\right)$ and $\mathrm{Hg}\left({ }^{3} \mathrm{P}_{0}\right)$ and the rate constant ratios already evaluated. The function $\beta$ is dependent only on the total pressure (see Equation VII). Thus for a given total pressure, the right-hand side of the equation should be a constant $=\left(1+\mathrm{k}_{12} j \mathrm{k}_{9}\right) / \hat{\mathrm{p}}$ at low $\left[\mathrm{O}_{2} \mathrm{j} / \mathrm{iCO} \mathrm{j}\right.$, should change regularly as $\left[\mathrm{O}_{2}\right] /[\mathrm{CO}]$ increases, and should again be a constant $=\left(\mathrm{k}_{13}+\mathrm{k}_{14}\right) / \mathrm{k}_{13}$ at high $\left[\mathrm{O}_{2}\right] /[\mathrm{CO}]$ ratios. The appropriate plots are shown in Figure 6.

For values of $\left[\mathrm{O}_{2}\right] /[\mathrm{CO}]$ between 0.1 and 1 and at a total pressure of 500 torr $\left(\Phi^{\prime \prime}\right)^{-1}$ is a constant. It rises to a plateau as $\left[\mathrm{O}_{2}\right] /[\mathrm{CO}]$ increases, but for $\left[\mathrm{O}_{2}\right] /[\mathrm{CO}]$ above 100 it increases once again. The behavior of $\left(\Phi^{\prime \prime}\right)^{-1}$ up to $\left[\mathrm{O}_{2}\right] /[\mathrm{CO}]=100$ is consistent with the prediction of Equation XI, but deviation occurs for $\left[\mathrm{O}_{2}\right] /[\mathrm{CO}]>100$. A decrease in $\Phi\left\{\mathrm{CO}_{2}\right\}$, hence an increase in $(\Phi)^{\prime \prime}$ must eventually occur as 
$\left[\mathrm{O}_{2}\right] /[\mathrm{CO}] \rightarrow \infty$, since either reaction 16 or 19 or both wili become important. Evidently reaction 16 or 19 becomes important at $\left[\mathrm{O}_{2}\right] /[\mathrm{CO}]=$ 100. At lower total pressures $\left(9^{\prime \prime}\right)^{-1}$ is still constant for $\left[\mathrm{O}_{2}\right] /[\mathrm{CO}]$ beiween 0.1 and 1 , but it increases more rapidly with increasing $\left[O_{2}\right]$; [CO] than at 500 torr, contrary to the prediction of Equation XI. It appears that at iower pressures the assumption that $R\{16\}+2 R\{19\}$ is negligible breaks down at lower $\left[\mathrm{O}_{2}\right] /[\mathrm{CO}]$. This is readily understandable if reaction 16 becomes important. If reaction 19 is important, it can be shown that $R(19\}$ could increase or decrease with pressure depending on the values of the rate constants.

From the curves in Figure 6 at low $\left[\mathrm{O}_{2}\right] /[\mathrm{CO}]$, the three values of $2\left(\Phi^{\prime \prime}\right)^{-1}=\left(1+\mathrm{k}_{12} i \mathrm{k}_{9}\right) i \beta$ are found to be 6.3, 5.3, and 4.4, respectively at 50, 100, and 500 torr total pressure. By adjusting the remaining parameters in Equation XI, the curves which best fit the data pointe in the applicable regions can be constructed. These theoretically computed curves are for values of $\left(k_{13}+k_{14}\right) /\left(k_{9}+k_{12}\right)=0.20$ and $k_{14} !$ $k_{13}=12$, and they are shown $a s$ the solid lines in Figure 6 . Both rate constant ratios have been obtained in previous studies. The value of 0.20 for $\left(k_{13}+k_{14}\right) /\left(k_{9}+k_{12}\right)$ is identical to that found by Heicklen and Johnston. ${ }^{2}$ The value of 12 for $\mathrm{k}_{14} / \mathrm{k}_{13}$ lies within the previously reported range of $7-33$. $^{1}$

In the low $\left[\mathrm{O}_{2}\right] /[\mathrm{CO}]$, constant $\left(\sigma^{\prime \prime}\right)^{-1}$ region, expression XI reduces to

$$
2\left(\Phi^{\prime \prime}\right)^{-1}=\left(1+\frac{k_{12}}{k_{9}}\right)\left(1+k_{11} / k_{10}[M]\right)
$$

Expression XII predicts that a plot of $2\left(\Phi^{1}\right)^{-1}$ vs. [M] $]^{-1}$ will be linear. This plot is presented in Figure 7. The intercept gives $\mathrm{k}_{12} / \mathrm{k}_{9}=3.25$ 


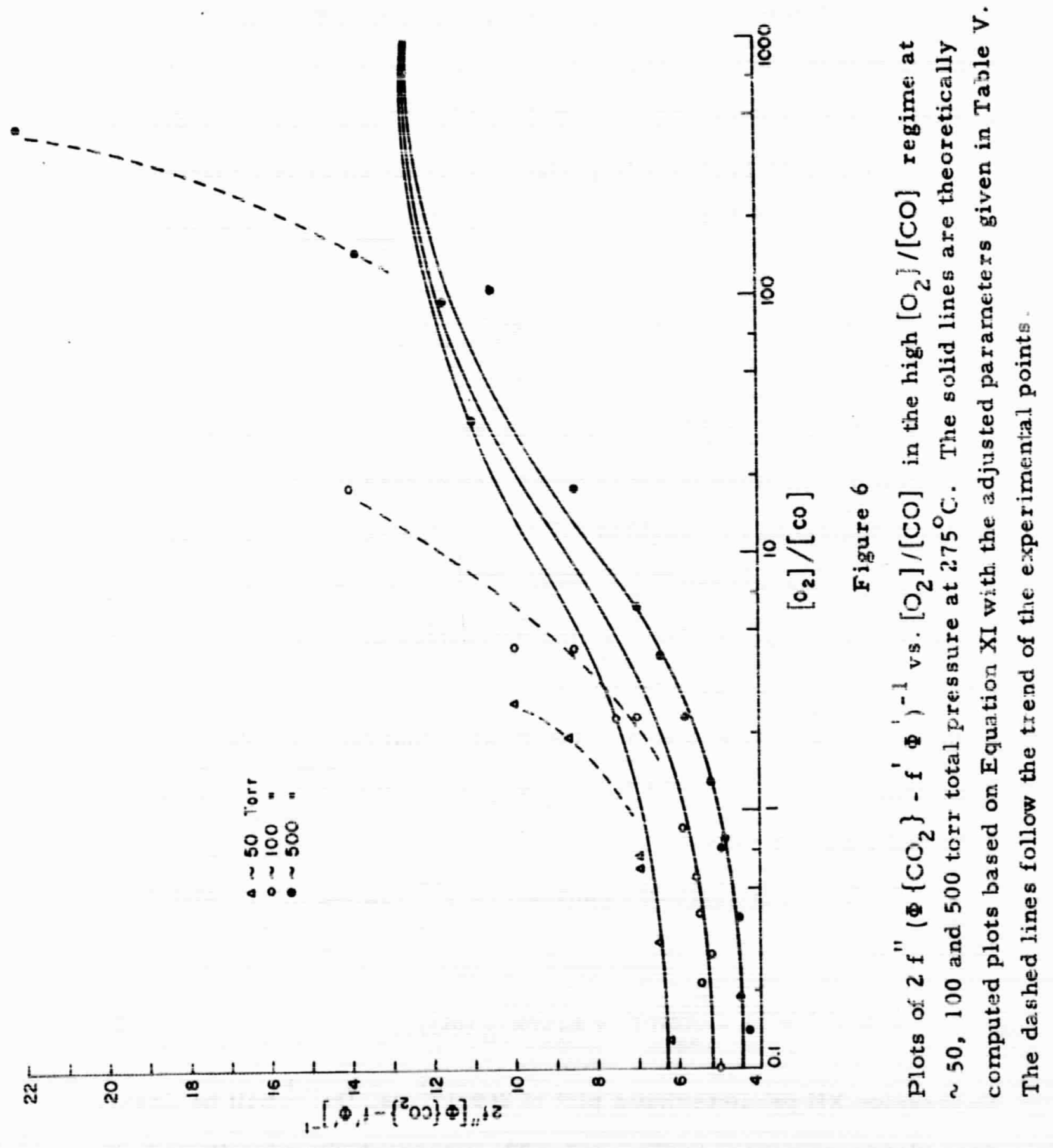




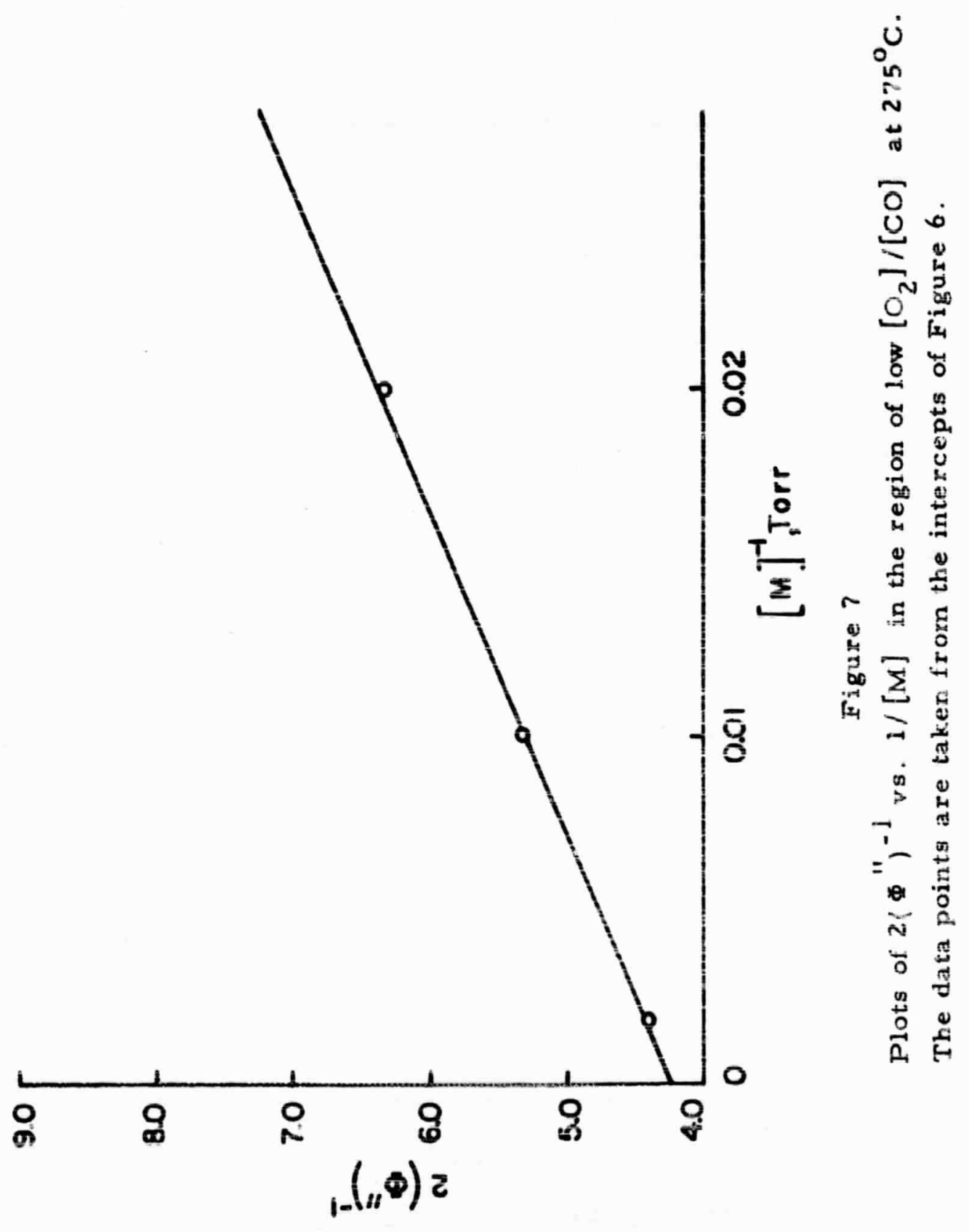


and the slope gives $\mathrm{k}_{11} / \mathrm{k}_{10}=25$ torr. The increase in $\Phi\left\{\mathrm{CO}_{2}\right\}$ upon raising the total pressure by increasing $\left[\mathrm{O}_{2}\right]+[\mathrm{CO}]$ at constant $\left[\mathrm{O}_{2}\right] /$ [CO] cannot be due to an increase in $\left[\mathrm{O}_{2}\right]$ or $[\mathrm{CO}]$, because if $\mathrm{CF}_{4}$ is used to increase the total pressure the same effect is observed. The fact that $\left(\Phi^{\prime \prime}\right)^{-1}$ vs. $[M]^{-1}$ is linear argues against the importance of reaction 23.

$$
\mathrm{CO}_{3} \rightarrow \mathrm{CO}_{2}+\mathrm{O}
$$

The recent study of $\mathrm{CO}_{3}$ formation via reaction 24 by DeMore and Dede ${ }^{8}$

$$
\left.\mathrm{O}^{1} \mathrm{D}\right)+\mathrm{CO}_{2} \rightarrow \mathrm{CO}_{3}
$$

showed that $\mathrm{CO}_{3}$ is formed only at pressures greater than $100 \mathrm{psi}$, indicating a lifetime of $10^{-11}$ io $10^{-12} \mathrm{sec}$. For the initiaily formed $\mathrm{CO}_{3}$. Our result for $\mathrm{k}_{11} / \mathrm{k}_{10}=25$ tor gives a lifetime for the $\mathrm{CO}_{3}$ formed in reaction 9 as $\sim 10^{-7} \mathrm{sec}$, assuming a collisionally induced predissociation rate of $10^{11} \mathrm{M}^{-1} / \mathrm{sec}$. This is in sharp contrast to the results of Demore and Dede, in particular when one sonsiders that reaction 9 is $166 \mathrm{kcal} / \mathrm{wole}$ more exothermic than reaction 24 , assuming the same $\mathrm{CO}_{3}$ structure. We conclude that the $\mathrm{CO}_{3}$ formed in reactions 9 and 24 must have different structures. Presumably the former is asymmetric OCOO, whercas the latter is the symmetric In the presence of TMP the mechanism predicts that for $\left[\mathrm{O}_{2}\right] /$ [CO] radios sufficiently low $(<2)$ so that reactions 13 and 14 are unimportant, and for [CO]/[TMP] ratios sufficiently low so that reaction 21 does not occur but sufficiently high to scavenge all the oxygen atoms, $\Phi\left\{\mathrm{CO}_{2}\right\}$ should be reduced by a factor of 2 from the value in the absence of TMP and $\Phi\left\{\mathrm{CO}_{2}\right\}=\Phi\{\mathrm{E}\}+\Phi\{\mathrm{A}\}$. Figure 1 and the data in Table III 
show that for the runs with [TMP] $\sim 1$ torr these expectaicions are approximately fulfilled. $\Phi\left\{\mathrm{CO}_{2}\right\}$ is not reduced exactly by a factor of 2 and $\Phi\left\{\mathrm{CO}_{2}\right\}$ is somewhat larger than $\Phi\{\mathrm{E}\}+\Phi(\mathrm{A}\}$ because only $70-$ $80 \%$ of the oxygen atouns are scavenged by TMP when [CO]/[TMP] = 400 , as can be shown using the relative rate constant for reactions 20 and $15\left(\mathrm{k}_{20} / \mathrm{k}_{15}=800\right.$ at $\left.548^{\circ} \mathrm{C}\right) .{ }^{10}$ The above quantum yield relationships show that for each $\mathrm{CO}_{2}$ molecule produced one oxygen atom ia also formed; therefore reactions 25 and 26 cannot bo important.

$$
\begin{aligned}
& \mathrm{CO}_{3}+\mathrm{O}_{2} \rightarrow \mathrm{CO}_{2}+\mathrm{O}_{3} \\
& \mathrm{CO}_{3}+\mathrm{CO} \rightarrow 2 \mathrm{CO}_{2}
\end{aligned}
$$

For the runs with $[\mathrm{TMP}]>3$ torr,$\Phi\{\mathrm{E}\}+\Phi\{\mathrm{A}\}>\Phi\left\{\mathrm{CO}_{2}\right\}$ and $\Phi\left\{\mathrm{CO}_{2}\right\}$ drops more than a factor of 2 from the value in the absence of TMP. It is clear that at these lower [CO]/[TMP] ratios the quenching of $\mathrm{O}_{2}^{*}$ by TMP takes place. From the variation $\Phi\left\{\mathrm{CO}_{2}\right\}$ as a function of the [CO]/[TMP] ratic an approximate value for $\left(k_{9}+k_{12}\right) / k_{21}$ can be calculated from $\Phi\left\{\mathrm{CO}_{2}\right\}=\Phi " \prime\left\{\mathrm{CO}_{2}\right\} \frac{\mathrm{k}_{21}[\mathrm{TMP}]}{\mathrm{k}_{21}[\mathrm{TMP}]+\left(\mathrm{k}_{9}+\mathrm{k}_{12}[\mathrm{CO}]\right.}+\Phi_{0}\left\{\mathrm{CO}_{2}\right\} \frac{\left(\mathrm{k}_{9}+\mathrm{k}_{12}\right)[\mathrm{CO}]}{\mathrm{k}_{21}[\mathrm{TMP}]+\left(\mathrm{k}_{9}+\mathrm{k}_{12}\right)[\mathrm{CO}]}$

\section{XIII}

where $\Phi " '\left\{\mathrm{CO}_{2}\right\}=0.050$ is the quantum yield of $\mathrm{CO}_{2}$ in the presence of TMP alone and $\Phi_{0}\left\{\mathrm{CO}_{2}\right\}$ is the quantum yield of $\mathrm{CO}_{2}$ when reaction 21 is unimportant (the runs at low [TMP], but otherwise comparable conditions). From the runs with [TMP] $=10$ and 22 torr and the appropriate values of $\Phi_{0}\left\{\mathrm{CO}_{2}\right\}$, the average value for $\left(\mathrm{k}_{9}+\mathrm{k}_{12}\right) / \mathrm{k}_{21}$ is calculated to be 0.06 . Combining this value with $\left(k_{13}+k_{14}\right) /\left(k_{9}+k_{12}\right)=0.20$ gives $\left(k_{13}+k_{14}\right) / k_{21}=$ 0.012 . 
The relative reactivity of $\mathrm{O}_{2}{ }^{*}$ with TMP measured in this inves tigation, $\left(\mathrm{k}_{13}+\mathrm{k}_{14}\right) / \mathrm{k}_{21}=0.012$, lies between the values for $\mathrm{C}_{2} \mathrm{H}_{4}$ and $\mathrm{C}_{3} \mathrm{~F}_{6}$ measured by Heicklen and Johnston. ${ }^{2}$ The relative reactivities based on $\mathrm{O}_{2}=1$ are the following: $\mathrm{C}_{3} \mathrm{~F}_{6}=5.6, \mathrm{TMP}=83, \mathrm{C}_{2} \mathrm{H}_{4} \geq 4700$. Thus the extent of fluorination strongly influences the reactivity of the olefin towards $\mathrm{O}_{2}{ }^{*}$.

In the earlier study of the reactivity of various gases with $\mathrm{O}_{2}{ }^{*}, 2$ Heicklen and Johnston observed that $\mathrm{CF}_{4}$ had no effect, but that $\mathrm{N}_{2}$ behaved in an unusual manner which was not explained. In this investigation we find that $\mathrm{N}_{2}$ does not increase $\Phi\left\{\mathrm{CO}_{2}\right\}$ in the high $\left[\mathrm{O}_{2}\right] /[\mathrm{CO}]$ regime as much as expected. The effect observed by Heicklen and Johnston was much more pronounced, but agrees qualitatively with the anomalous pressure effect observed in this study. The most reasonable explanation of the earlier results and those obtained in this work is that $\mathrm{N}_{2}$ deactivates $\mathrm{O}_{2}{ }^{*}$ to a state of different reactivity. 


\section{REFERENCES}

1. D. Volman, Advan. Photochem, , 1,43 (1963).

2. J. Heicklen and T. Johnston, I, Phys. Chem, 71, 1391 (1967).

3. J. Heicklen, Advan. Photochem. , 7,57 (1969).

4. M, D. Scheer and T. J. Fine, J. Chem. Phys., 36, 1264 (1962k.

5. G. Karl, P. Kruus, and J. C. Polanyi, J. Chem. Phys., 46, 224, (1967).

6. G. London, A. C. Vikis, and D. J. LeRoy, Can. J. Chem. , 48, $1480(1970)$.

7. A. B. Callear and G. J. Williams, Trans, Faraday Soc., 60, 2158 (1967).

8. W. B. DeMore and C. Dede, J. Phys. Chem., 74, 2621 (1970), and references therein.

9. S. J. Moss and K. R, Jennings, Trans, Faraday Soc, 64, 686 (1968).

10. R. Simonaitis and J. Heicklen, J. Chem. Phys, in press: (19,71).

11. R. J. Cvetanović, Advan. Photochem., 1, 115 (1961).

12. J. G, Calvertand J. N. Pitts, Jr., "Photochemistry," John Wiley and Sons, Inc., New York, N. Y. (1966), p. 81 .

13.. N.. G. Moll, D. R. Clutter, and W. E. Thompson, I. Chem. Phys., 45, $4469(1966)$.

14. E. Weissberger, W. H. Breckenridge, and H, Taube, J. Chem. Phys., 47, 1764 (1967).

15. N. Cohen and J. Heicklen, Comprehensive Chemical Kinetics Vol. 6, (ed. C. H. Bamford and C, F. H. Tipper) Elsevier, in press.

16. R. Simonaitis, J. Heicklen, M. McGuire, and R. Bernheim, unpublished results (1970). $\quad$

17. Reference 12, p. 76. 
$-40-$

18. K. D. Foster and G. H. Kimbeil, J. Chem, Phys., 53, 2539 (1970). 


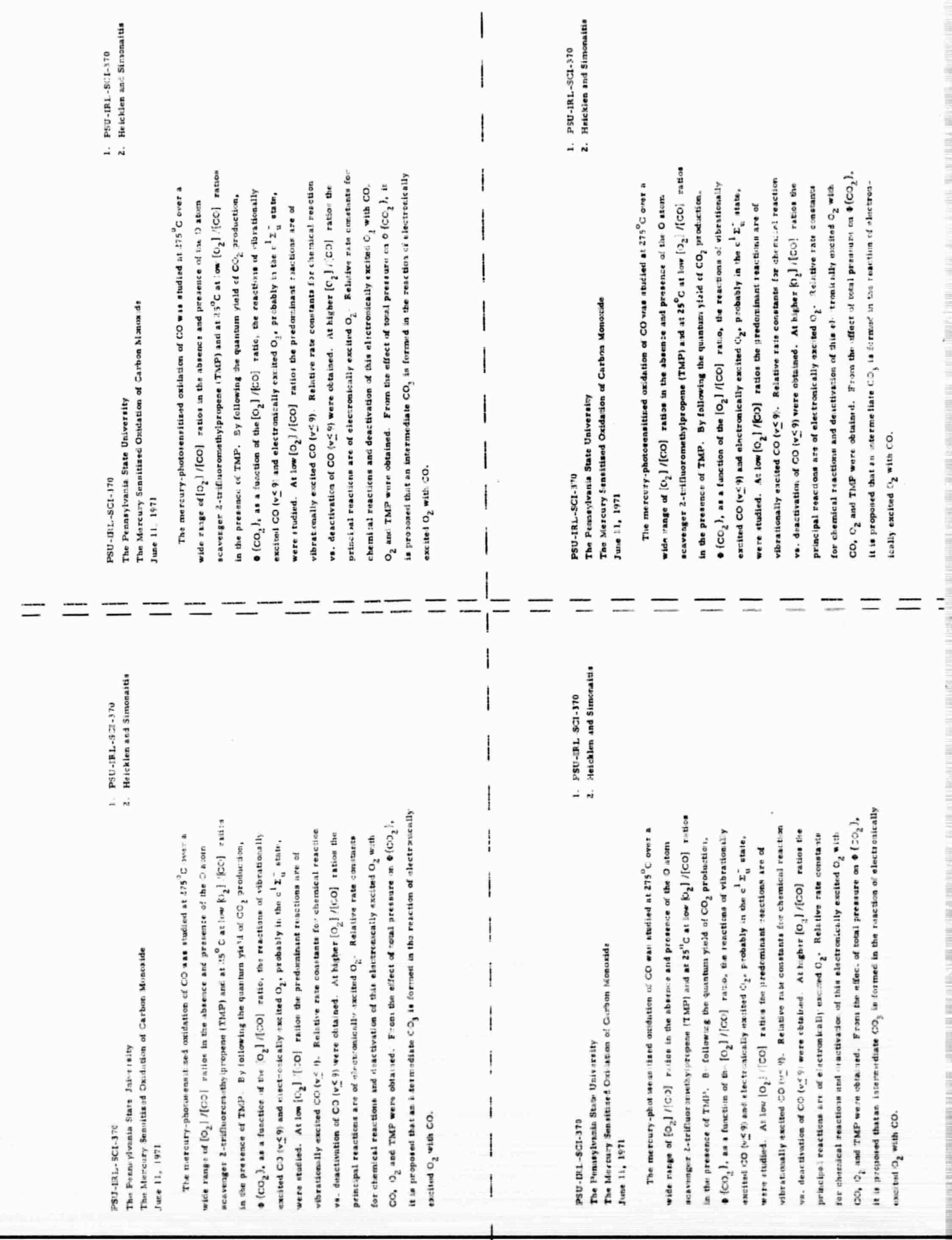




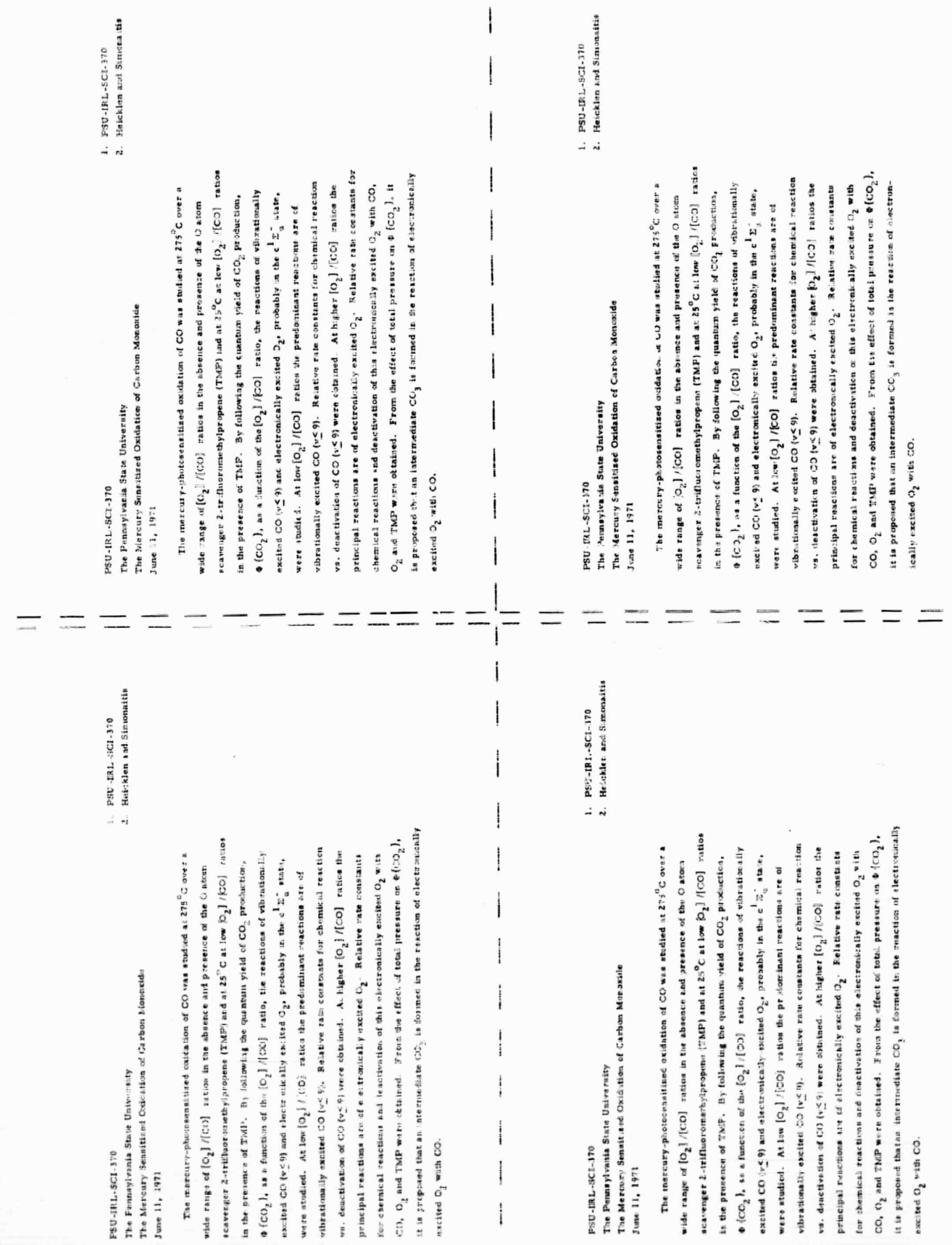

